\begin{tabular}{|l|r|}
\hline SEP 2199822 engineering data transmittal & $\begin{array}{r}\text { Page } 1 \text { of } \frac{\$}{9} \\
\text { Sta } 37\end{array}$ \\
\hline
\end{tabular}

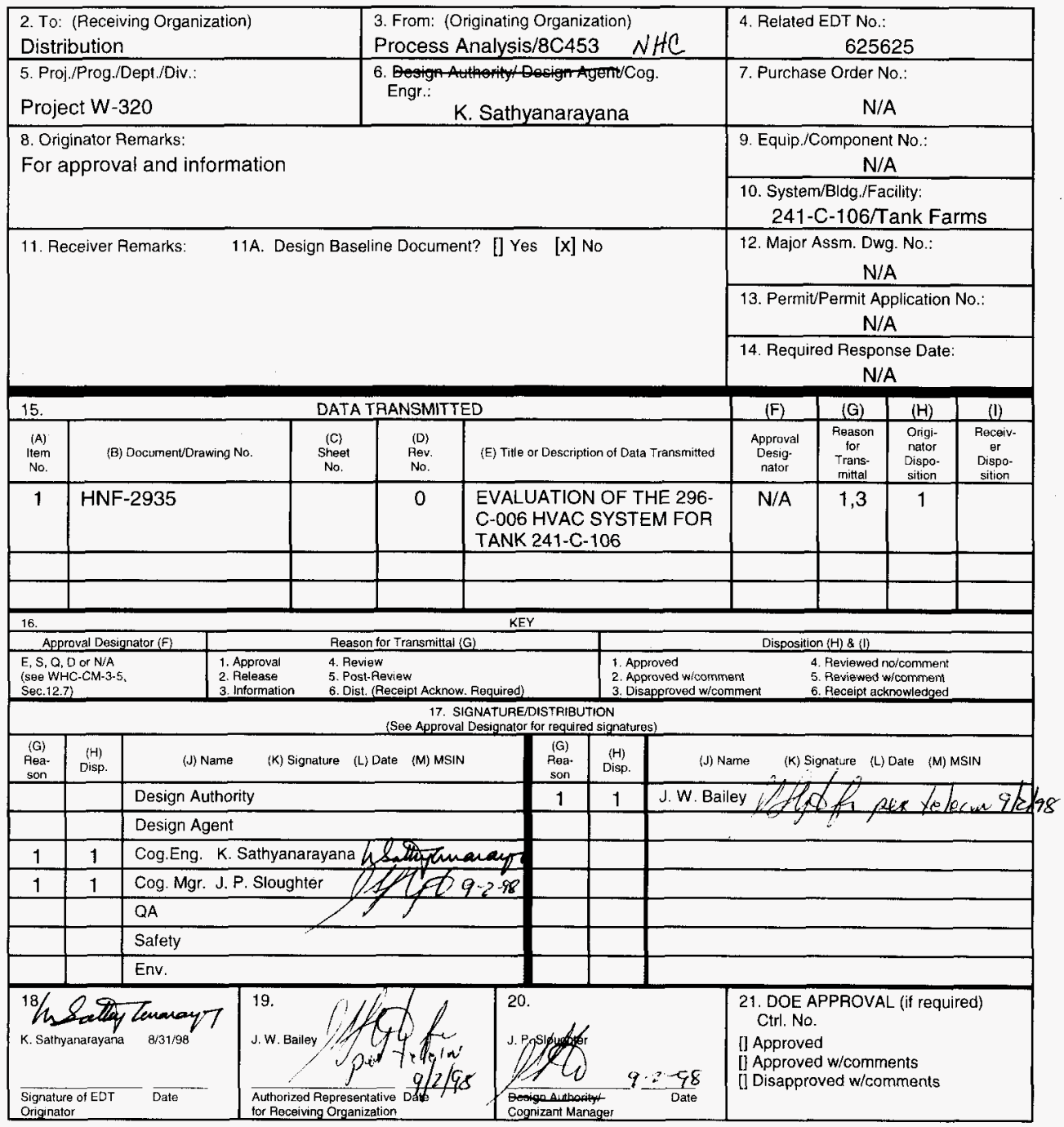

BD-7400-172-2 (05/96) GEF097 


\title{
EVALUATION OF THE 296-C-006 HVAC SYSTEM FOR TANK 241-C-106
}

\section{K. Sathyanarayana}

Numatec Hanford Corporation, Richland, Richland, WA 99352

U.S. Department of Energy Contract DE-AC06-96RL13200

\author{
EDT/ECN: $625625 \quad$ UC: 12104 \\ Org Code: 8C453 Charge Code: D2M76 HANA0600

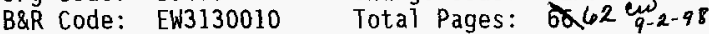

Key Words: Tank 241-C-106, Waste Retrieval Sluicing System, 296-C-006 HVAC System, 296-P-16 Chi11er System

Abstract: Prior to the sluicing of Tank 241-C-106, the 296-P-16 ventilation system will be shutdown and the $296-C-006$ ventilation system operation will be initiated. The 296-C-006 system has a low once through flow with an additional recirculation flow in the tank dome space. A minimum dome pressure of -3 in W.G. is necessary for safe operation. An evaluation of the system has been performed. The results of the study show that adequate done space vacuum can be achieved if the pump pits in Tank 241-6-106 are sealed.

TRADEMARK DISCLAIMER. Reference herein to any specific commercial product, process, or service by trade name, trademark, manufacturer, or otherwise, does not necessarily constitute or imply its endorsement, recommendation, or favoring by the United States Government or any agency thereof or its contractors or subcontractors.

Printed in the United States of America. To obtain copies of this document, contact: Document Control Services, P.0. Box 950, Mailst op H6-08, Richland WA 99352, Phone (509) 372-2420; Fax (509) 376-4989.

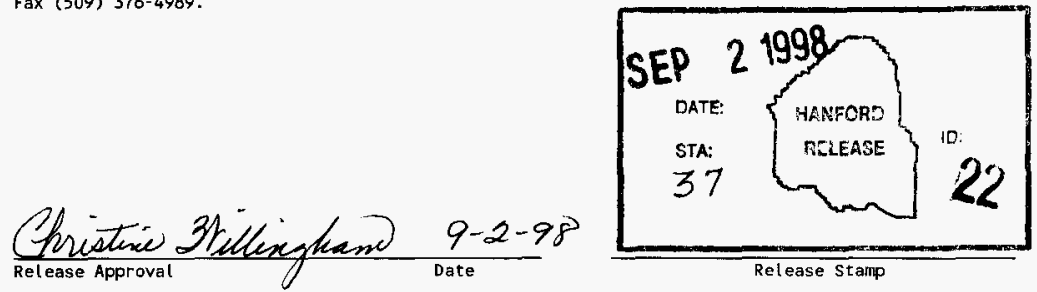

\section{Approved for Public Release}


HNF-2935, Rev 0

\title{
EVALUATION OF THE 296-C-006 HVAC SYSTEM FOR TANK 241-C-106
}

\author{
D.M. Ogden \\ John Marvin, Inc. \\ Richland, Washington \\ K. Sathyanarayana \\ Numatec Hanford Corporation \\ Richland, Washington
}

Issued by

Numatec Hanford Corporation

Richland, Washington

for the

\author{
U.S. DEPARTMENT OF ENERGY \\ RICHLAND OPERATIONS OFFICE \\ RICHLAND, WASHINGTON
}




\section{HNF-2935, Rev 0}

\section{CONTENTS}

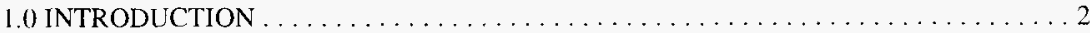

2.0 SCOPE AND SUPPORTING INFORMATION $\ldots \ldots \ldots \ldots \ldots \ldots \ldots \ldots \ldots \ldots$

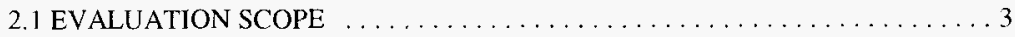

2.2 TANK 241-C-106 VENTILATION SYSTEM DESCRIPTION . . . . . . . . 4

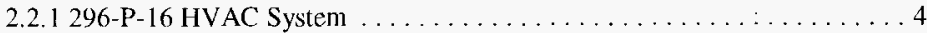

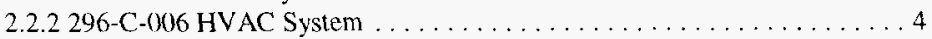

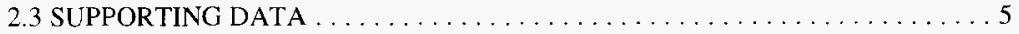

2.3.1 296-P-16 System Ventilation Flow Test . . . . . . . . . . . . . 5

2.3.2 Tank 241-C-106 Flammable Gas Process Test . . . . . . . . . . . 5

2.3.3 Tank 241-C-106 1992 Ventilation Outage . . . . . . . . . . . 6

2.3.4 System $296-C-006$ ATP Test . . . . . . . . . . . . . . . . . 6

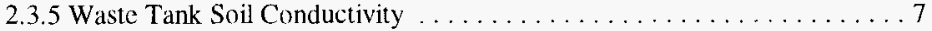

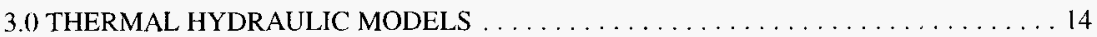

$3.1296-\mathrm{P}-16$ HVAC SYSTEM GOTH MODEL $\ldots \ldots \ldots \ldots \ldots \ldots \ldots \ldots \ldots \ldots$

$3.2296-\mathrm{C}-006$ HVAC SYSTEM GOTH MODEL $\ldots \ldots \ldots \ldots \ldots \ldots \ldots \ldots \ldots \ldots$

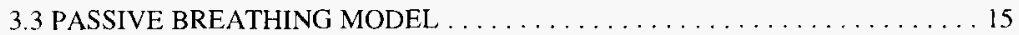

4.0 THERMAL HYDRAULIC MODEL BENCHMARK . . . . . . . . . . . . 20

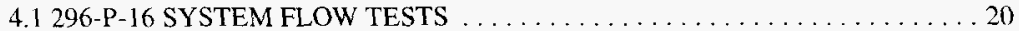

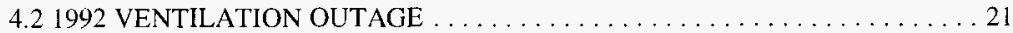

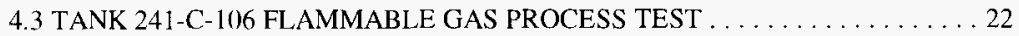

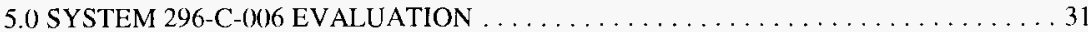

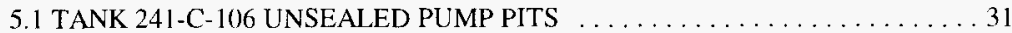

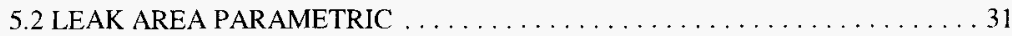

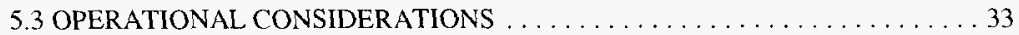

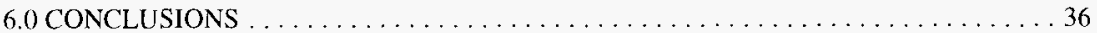

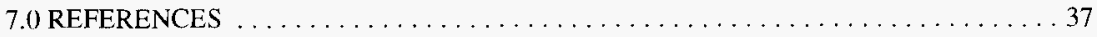

A-1.0 INTRODUCTION . . . . . . . . . . . . . . . . . . . . . .

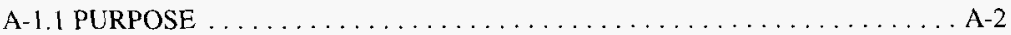

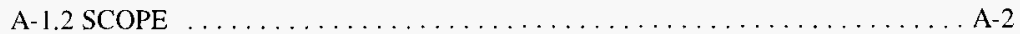

A-2.0 THERMAL HYDRAULIC MODEL $\ldots \ldots \ldots \ldots \ldots \ldots \ldots \ldots \ldots \ldots \ldots$ A-2 
HNF-2935, Rev 0

A-3.0 EVALUATION OF CHILLER . . . . . . . . . . . . . . . . A 6

A-3.1 CHILLER OPERATION WITH UNSEALED PUMP PITS $\ldots \ldots \ldots \ldots \ldots$ A-6

A-3.2 NO CHILLER OPERATION $\ldots \ldots \ldots \ldots \ldots \ldots \ldots \ldots \ldots \ldots \ldots \ldots \ldots \ldots \ldots$

A-3.3 CHILLER OPERATION . . . . . . . . . . . . . . . A-7

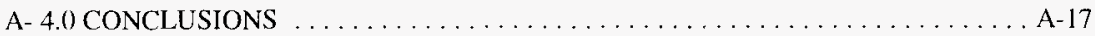

\section{FIGURES}

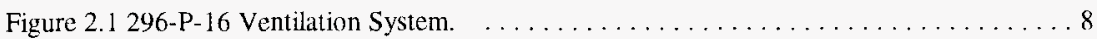

Figure 2.2 296-C-(006 Ventilation System. . . . . . . . . . . . . . . . . . 9

Figure 2.3 Flammable Gas Test Hydrogen Concentration ................... 10

Figure 2.4 Dome Space Temperature During Flammable Gas Tests. . . . . . . . . . . 11

Figure 2.5 Dome Temperatures For The 1992 C-106 Ventilation Outage. . . . . . . . . . 12

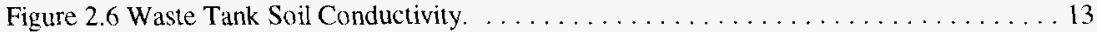

Figure $3.1296-\mathrm{P}-16$ HVAC System GOTH Model. . . . . . . . . . . . . . . . . . . 17

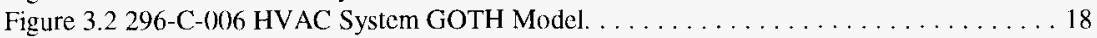

Figure 3.3 Tank 241-C-106 Passive Breathing GOTHIC Model. . . . . . . . . . . . 19

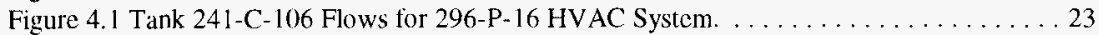

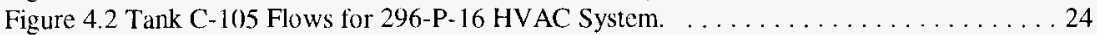

Figure 4.3 Predicted Passive Breathing Rate for Tank 241-C-106 Ventilation Outage. . . . . 25

Figure 4.4 Dome Space Temperature Comparison for 1992 Ventilation Outage. . . . . . . . . 26

Figure 4.5 Predicted Hydrogen Concentration for Unsealed Pump Pits. . . . . . . . . . . . 27

Figure 4.6 Comparison With Flammable Gas Test Dome Space Temperature. . . . . . . . . . 28

Figure 4.7 Hydrogen Concentration for Tank 241-C-105 Leak Area. ................ 29

Figure 4.8 Hydrogen Concentration for Sealed Pump Pits in Tank 241-C-106 . . . . . . . 30

Figure 5.1 Tank 241-C-106 Vacuum Pressure for Leak Area Variation. . . . . . . . . . . . . 34

Figure 5.2 Tank 241-C-106 Vacuum Pressure (Expanded Scale). . . . . . . . . . . . 35

Figure A-2.1 GOTHIC Tank 241-C-106 Model. . . . . . . . . . . . . . . . A-4

Figure A-2.2 Monthly Average Ambient Temperaturc Data. ................ A-5

Figure A-3.1 Dome and Riser 8 Waste Temperature With Unsealed Pump Pit. . . . . . . . A-9

Figure A-3.2 Comparison of With PCP Temperature Criteria With Unsealed Pump Pits. . . A-10

Figure A-3-3 1998 Waste Temperature Comparison With Temperature Criteria, Unsealed.

Figure A-3.5 Dome and Riser 8 Waste Temperature With No Waste Chilling. . ...... A-13

Figure A-3.6 Comparison With PCP Temperature Criteria With No Waste Chilling. . . . . A-14

Figure A-3.7 Dome and Riser 8 Waste Temperature With Sealed Pump Pits. ......... . A-15

Figure A-3.8 Comparison With PCP Temperature Criteria With Sealed Pump Pits. . . . . . A-16 


\section{HNF-2935, Rev 0}

Figure $2.1296-\mathrm{P}-16$ Ventilation System. $\ldots \ldots \ldots \ldots \ldots \ldots \ldots \ldots \ldots \ldots \ldots \ldots$

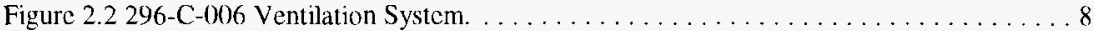

Figure 2.3 Flammable Gas Test Hydrogen Concentration . . . . . . . . . . . . . . 10

Figure 2.4 Dome Space Temperature During Flammable Gas Tests. . . . . . . . . . . . . 11

Figure 2.5 Dome Temperatures For The 1992 C-106 Ventilation Outage. . . . . . . . . . 12

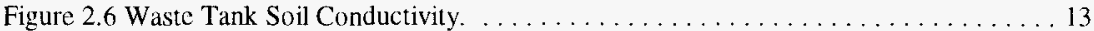

Figure 3.1 296-P-16 HV AC System GOTH Model. . . . . . . . . . . . . . . . . . . . . . 17

Figure $3.2296-\mathrm{C}-006$ HVAC System GOTH Model. . . . . . . . . . . . . . . . . . . . 18

Figure 3.3 Tank 241-C-106 Passive Breathing GOTHIC Model. . . . . . . . . . . . . . 19

Figure 4.1 Tank 241-C-106 Flows for 296-P-16 HVAC System. . . . . . . . . . . . . 23

Figure 4.2 Tank $\mathrm{C}-105$ Flows for 296-P-16 HVAC System. . . . . . . . . . . . . . 24

Figurc 4.3 Predicted Passive Breathing Rate for Tank 241-C-106 Ventilation Outage. . . . . 25

Figure 4.4 Dome Space Temperature Comparison for 1992 Ventilation Outage. . . . . . . . . 26

Figure 4.5 Predicted Hydrogen Concentration for Unsealed Pump Pits. . . . . . . . . . . 27

Figure 4.6 Comparison with Flammable Gas Test Dome Space Temperature. . . . . . . . . . 28

Figure 4.7 Hydrogen Concentration for Tank 241-C-105 Leak Area. . . . . . . . . . . . . 29

Figure 4.8 Hydrogen Concentration for Sealed Pump Pits in Tank 241-C-106 . . . . . . . . 30)

Figure 5.1 Tank 241-C-106 Vacuum Pressure for Leak Area Variation. . . . . . . . . . . . . 34

Figure 5.2 Tank 241-C-106 Vacuum Pressure (Expanded Scale). . . . . . . . . . . . . 35

Figure A-2.1 GOTHIC Tank 241-C-106 Model . . . . . . . . . . . . . . . . A-4

Figure A-2.2 Monthly Average Ambient Temperature Data. . . . . . . . . . . . A-5

Figure A-3.1 Dome and Riser 8 Waste Temperature with Unsealed Pump Pit. . . . . . . . . A-9

Figure A-3.2 Comparison of with PCP Temperature Criteria with Unsealed Pump Pits. . . A-10

Figure A-3-3 1998 Waste Temperature Comparison with Temperalure Criteria, Unsealed. . A-1 1

Figure A-3.4 Maximum Waste Temperature with Unsealed Pump Pits. . . . . . . . . . A-12

Figure A-3.5 Dome and Riser 8 Waste Temperature with no Waste Chilling. . . . . . . . A-13

Figure A-3.6 Comparison with PCP Temperature Criteria with no Waste Chilhing. . . . . . A-14

Figure A-3.7 Dome and Riser 8 Waste Temperature with Sealed Pump Pits. . . . . . . . A-15

Figure A-3.8 Comparison with PCP Temperature Criteria with Sealed Pump Pits. . . . . . A-16

\section{TABLES}

Table 2.1 Summary of Ventilation Flow Data $\ldots \ldots \ldots \ldots \ldots \ldots \ldots \ldots \ldots \ldots$

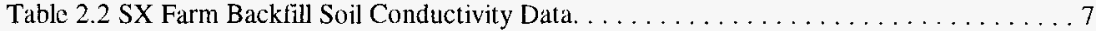

Table 4.1 Summary of Flows for 296-P-16 System Flow Test. . . . . . . . . . . . . . . . . 21

Table 5.1 Summary of Flows for 296-C-006 HVAC System with Unsealed Leak Area. . . . . 31

Table 5.2 Summary of Flows for 296-C-(006 HVAC System with C-105 Leak Area. . . . . . 32

Table 5.3 Summary of Flows for 296-C-006 HVAC System with Sealed Pump Pit. . . . . . . 32

Table 5.4 Summary of Flows and Dome Vacuum for 296-C-(006 HVAC System. . . . . . . . 33 
HNF-2935, Rev 0

\section{APPENDICES}

APPENDIX A. Tank 241-C-106 CHILLER PERFORMANCE . . . . . . . . . . . A-I

APPENDIX B. INFORMATION FOR QUALITY ASSURANCE RECORDS $\ldots . . .$. B-1 


\section{HNF-2935, Rev 0}

\section{0) INTRODUCTION}

Prior to the sluicing of Tank 241-C-106, the 296-P-16 ventilation system will be shut down and the 296-C-006 ventilation system operation initiated. The 296-P-16 ventilation system is a high volumetric flow, once-through system. The 296-C-(0)6 system is a low once-through flow system with an additional re-circulation flow in the tank dome space. A minimum dome space vacuum pressure of 0.3 Inches Water Gauge (Inch W.G.) is required for operation. This minimum vacuum may be difficult to achieve with the low once-through flow of the 296-C-0)(06 system. An evaluation of the 296-C-006 system has been performed to estimate the dome space vacuum for a range of flows, and expected lcak areas into the pump pits. This study has shown that adequate dome space vacuum can be achieved if the pump pits in Tank 241-C-106 are scaled. An evaluation of the Flammable Gas Process Test of June 1997 has demonstrated that pump pits can be sealed to an adequate level.

A discussion of the scope of the evaluation and supporting data is provided in Section 2.0. Data from a System 296-P-16 flow test was used to benchmark a computer flow model for Tank 241-C-106. The data provided important information about the leak areas for Tanks 241C-105 and 106. A 1997 Flammable Gas Process Test for Tank 241-C-106 was used to determine the leak area for Tank 241-C-106 when the pump pits were sealed as they were for the process test. The passive breathing model used for this evaluation was benchmarked using the dome space temperature data from the 1992 ventilation outage for Tank $241-\mathrm{C}-106$. The thermal hydraulic models used for the evaluation are presented in Section 3.0. These include a GOTH model of the 296-P-16 and 296-C-(10)6 ventilation systems and a GOTHIC model for passive breathing for Tank 241-C-106. The thermal hydraulic models used for the evaluation were benchmarked with the data presented in Section 2.0. The results of the benchmark analyses are presented in Section 4.0. The evaluation of the System 296-C-(006 using the benchmarked models, is provided in Section 5.0. Section 6.0 presents the conclusions of the evaluation.

The Project W-320 Process Control Plan (PCP) (Carothers 1998) requires that Tank 241C. 106 be cooled to near winter conditions by opcrating the $296-\mathrm{P}-16$ ventilation system inlet chiller. Chiller operation for Tank 241-C-106 was initiated 6/30/98. A secondary purpose of this report is to provide an evaluation to determine if winter conditions can be achieved in the waste by the end of September. The evaluation of the Tank 241-C-106 waste temperatures for chiller operation prior to sluicing is provided in Appendix A of this report. 


\section{HNF-2935, Rev (}

\section{1) SCOPE AND SUPPORTING INFORMATION}

Section 2.1 provides an overview of the scope of the evaluation of the 296-C-(006 ventilation system. A description of the 296-P-16 and 296-C- 0066 ventilation systems is provided in Section 2.2. Supporting data used for the evaluation is presented in Section 2.3.

\subsection{EVALUATION SCOPE}

The evaluation of the 296-C-(0)6 ventilation system was performed using computer models of the ventilation system. The thermal hydraulic computer models were used to assess the flow and dome space pressure characteristics of the system, for the expected range of operating parameters. The computer models were benchmarked with data presented in Section 2.3 .

Computer models were developed for both the 296-P-16 and 296-C-(006 ventilation systems using the GOTH and GOTHIC computer codes. In July of 1997, 1low tests were conducted for the 296-P-16 Ventilation System. The inlet filter and tank outlet flows were measured for Tanks $241-\mathrm{C}-105$ and 106 . These data were used to benchmark the GOTH model and determine the pump pit leak areas.

During the C Farm Ventilation Flow Test of 1997, the pump pits in Tank 241-C-105 were sealed while the pits in Tank 241-C-106 were unsealed. However, the pump pits in Tank 241-C106 were sealed during the Flammable Gas Process Tests performed for Tank 241-C-106 during June of 1997. A GOTHIC model of Tank 241-C-106 was developed to model the natural breathing rate of Tank 241-C-106 during the Flammable Gas Process Test. The GOTHIC model was then used to determine the leak area required to predict the hydrogen concentrations observed in the process test. This evaluation determined the probable leak area of sealed pump pils for Tank 241-C-106.

The GOTHIC model used to evaluate the Flammable Gas Process Test was benchmarked using data from the Tank 241-C-106 ventilation outage of 1992. The GOTHIC model was used to predict the dome space temperatures which were dependent upon the passive breathing rate during the ventilation outage.

The benchmarked GOTH model was used to evaluate the dome space vacuum for the 296-C-(006 system, using the leak areas determined from the ventilation flow tests and the evaluation of the Flammable Gas Test. Parametric analyses were also performed for the Tank 241-C-106 leak area and tlow rate of the 296-C-(0)6 Ventilation System. 


\section{HNF-2935, Rev 0}

\subsection{TANK 241-C-106 VENTILATION SYSTEM DESCRIPTION}

Tank 241-C-106 is currently operating with the 296-P-16 ventilation system. During sluicing, the Project W-320 296-C-006 ventilation system will replace the current system. Both systems are described in the following section.

\subsubsection{6-P-16 HVAC System}

The 296-P-16 is a high capacity once-through ventilation system (Carothers 1998). A schematic of the system is shown in Figure 2.1. The fan draws suction from the outlet of Tank 241-C-106 and 241-C-105. Tank 241-C-104 is connected to Tank 241-C-105 by an overflow line indicated by the dashed arrow in Figure 2.1. The 296-P-16 Exhaust Skid contains a heater, a scries of HEPA lilters and the exhaust fan. The fan is capable of over $3300 \mathrm{cfm}$ flow.

Approximately $15 \%$ of the exhaust fan flow is drawn from Tank $241-\mathrm{C}-105$, with the remainder drawn from 241-C-106.

The inlet filter system supporting the 296-P-16 exhauster, includes an inlet air cooling coil provided by Project W-320, which will be used prior to sluicing to cool Tank 241-C-106 to near winter conditions. The cooling coil for the chiller system is located between the inlet filters and the inlet riser for Tank 241-C-106 as shown in Figure 2.1. This system is capable of providing $34^{\circ} \mathrm{F}$ chilled inlet air to Tank 241-C-106.

\subsubsection{6-C-006 HVAC System}

The 296-C-(006 ventilation system was designed for Project W-320. It provides a minimum once-through flow for tank cooling and a re-circulation flow loop, which provides defogging of the dome space during sluicing. System 296-C-006 is shown in Figure 2.2. The exhaust fan located on the Exhaust Skid draws it's suction from Tank 241-C-106 dome space only. Tank 241-C-105 is connected to Tank 241-C-106 through an overflow line. The exhaust fan is capable of $360 \mathrm{cfm}$ flow (Carothers 1998).

The Process Building shown in Figure 2.2 contains the equipment for the re-circulation line. Suction for the re-circulation line is drawn downstream of the condenser. The flow is heated and returned to the tank inlet. The flow rate of the re-circulation flow is $860 \mathrm{cfm}$.

Operation of the 296-P-16 and 296-C-(0)6 ventilation systems are mutually exclusive since they use some shared ducting There is also a single chiller providing cooling for the two systems which does not have sufficient capacity for both systems to operate simultaneously. 
HNF-2935, Rev 0

\subsection{SUPPORTING DATA}

This section provides a description of supporting information and data, used for bench marking the thermal hydraulic model, used for the cvaluation of the $296-\mathrm{C}-006$ ventilation system.

\subsubsection{6-P-16 System Ventilation Flow Test}

In July of 1997, ventilation flow measurements were obtained for Tanks 241-C-105 and 106 (Lohrasbi 1998). Table 2.1 shows the measured ventilation flow rates for the July 1997 flow tests. Both inlet filter and tank outlet flows were measured. The tank leak flows can be inferred from these measurements. The pump pits for Tank $241-\mathrm{C}-105$ were sealed during the flow tests. This is clearly evident by comparing the inlet filter and outlet flows. Over $80 \%$ of the flow enters the tank through the inlet filters. The pump pits in Tank 241-C-106 were unsealed during this test. As a consequence, the inlet filter flow is less than $50 \%$ of the outlet flow. The remainder of the flow enters through the leak paths in the pump pits.

Table 2.1 Summary of Ventilation Flow Data

\begin{tabular}{|c|c|c|c|c|}
\hline Tank Identification & $\begin{array}{c}\text { Measured Inlet } \\
\text { Filter Flow } \\
\text { (CFM) }\end{array}$ & $\begin{array}{c}\text { Measured } \\
\text { Tank Outlet Flow } \\
\text { (CFM) }\end{array}$ & $\begin{array}{c}\text { Measured C-Farm } \\
\text { Exhaust Flow } \\
\text { (CFM) }\end{array}$ & Measurement Date \\
\hline $241-$ C-105 & 438 & 541 & & $7 / 23 / 97$ \\
\hline $241-$ C-106 & 1337 & 2831 & 3346 & $7 / 24 / 97$ \\
\hline $241-$ C-106* & 1393 & & & $8 / 1 / 97$ \\
\hline
\end{tabular}

* Inlet HEPA filters failed DOP tests and were replaced before $8 / 1 / 97$

Inlet HEPA filters were replaced after the measurements on $7 / 23$ and $7 / 24$. The subsequent measurement on 8/1/97 for Tank 241-C-106 inlet flow, was higher than previous measurements as expected for a clean filter. The data measured prior to the HEPA filter replacement was used for the analyses. It is slightly more conservative in that the leak flow would be expected to be larger.

\subsubsection{Tank 241-C-106 Flammable Gas Process Test}

In June of 1997 a process test was conducted in Tank 241-C-106. The purpose of the test was to determine the release rate of tlammable gas in the tank dome space. The test was conducted by shutting down the ventilation system and measuring the flammable gas 


\section{HNF-2935, Rev 0}

concentrations in the dome space. During normal ventilation operations, the flammable gas concentration are too low for a reliable measurement. During the Flammable Gas Process Test the active ventilation was eliminated, resulting in passive breathing only, in the tank for a period of 48 hours. The pump pits for Tanks $241-\mathrm{C}-105$ and 106 were sealed during this test. The measured hydrogen concentration for the Flammable Gas Process Test is shown in Figure 2.3. The linear nature of the hydrogen concentration is an indication that the natural breathing rates werc very low during the test.

The dome space temperature (Riser 14, TC 8) is shown in Figure 2.4. The dome space begins to heat-up due to the loss of ventilation. The Process Test was started at 1400 hours on 6/4/97. Data is reported at 2400 hours each day. The circles shown in Figure 2.4 are extrapolated values, indicating the possible dome temperatures at the start and end of the process test.

\subsubsection{Tank 241-C-106 1992 Ventilation Outage}

In January of 1992, the 296-P-16 ventilation system became inoperable for a period of six months (Bander 1993). During this time, the tank was cooled by soil conduction and passive breathing only. The passive breathing provided a small amount of sensible heat removal, but a more significant amount of evaporative heat transfer. The dome space temperature during the ventilation outage was directly related to the passive breathing rate. These data provide a good benchmark for the GOTHIC passive breathing model, used for the evaluation of the Flammable Gas Proccss Test of 1997.

The dome space temperatures are shown in Figure 2.5. The ventilation outage began between January 16 and January 25,1992 . The temperature rapidly increased until passive breathing and soil conduction are able to remove the tank heat. The ambient air temperature is shown in Figure 2.5. After one to two months, a quasi-steady state was reached and the dome temperature increase at the rate of the ambient air temperature.

In June of 1992 the ventilation flow was re-established. The dome space temperature rapidly returns to expected seasonal temperatures.

\subsubsection{System 296-C-006 ATP Test}

An acceptance test has been conducted for the 296-C-(006 Ventilation System (Bailey 1998). The acceptance tests for the 296-C-006 exhaust system demonstrated that the ventilation system could provide $360 \mathrm{cfm}$ exhaust flow from Tank $241-\mathrm{C}-106$. Therefore, no evaluation was conducted for the ventilation system downstream of Tank 241-C-106. The analyses performed assumed flows up to $360 \mathrm{cfm}$. 
HNF-2935, Rev 0

\subsubsection{Waste Tank Soil Conductivity}

The GOTHIC passive breathing models predict the breathing rate based upon dome space temperatures. This temperature depends upon the heat transfer through soil conduction, sensible heat removal, and evaporation. There is limited soil thermal conductivity data for SX Farm back fill soils (Bouse 1975). These data were used for the passive ventilation models.

Table 2.2 provides a summary of the soil conductivity data. The soil samples were heated to the indicated temperatures and vibrated for 2 minutes to provide some consolidation. However, the samples would not be as compact as the settled soils which now surround the tanks. The actual soil conductivities would be higher than the measured data.

The soil conductivity data are shown in graphical form in Figure 2.6. The average of the data is just under $0.30 \mathrm{Btu} / \mathrm{hr}-\mathrm{ft}-{ }^{-} \mathrm{F}$. The average plus 3 standard deviations is approximately 0.6 $\mathrm{Btu} / \mathrm{hr}-\mathrm{ft}-{ }^{\circ} \mathrm{F}$. A thermal conductivity of $0.6 \mathrm{Btu} / \mathrm{hr}-\mathrm{ft}-{ }^{\circ} \mathrm{F}$ was used for the passive breathing thermal models. The higher value accounted for soil compaction given good results for the benchmark with the 1992 ventilation outage data.

Table 2.2 SX Farm Backfill Soil Conductivity Data.

\begin{tabular}{|c|c|c|c|}
\hline Sample & Soil Sample Number & $\begin{array}{l}\text { Measurement } \\
\text { Temperature }\left({ }^{\circ} \mathrm{F}\right)\end{array}$ & $\begin{array}{l}\text { Thermal } \\
\text { Conductivity } \\
\text { (Btu/hr-ft- F) }\end{array}$ \\
\hline 1 & sand & 76 & 0.21 \\
\hline 2 & slightly muddy sand & 75 & 0.17 \\
\hline 3 & gravely sand & 74 & 0.22 \\
\hline 4 & sandy mud & 79 & 0.19 \\
\hline 5 & slightly gravely muddy sand & 77 & 0.24 \\
\hline 6 & sandy gravel & 75 & 0.45 \\
\hline 7 & slightly muddy gravely sand & 76 & .39 \\
\hline 8 & gravely muddy sand & 76 & .32 \\
\hline 9 & slightly gravely sand & 72 & .29 \\
\hline \multirow[t]{3}{*}{10} & muddy sandy gravel & 78 & .34 \\
\hline & Average & & .28 \\
\hline & Standard Deviation & & .09 \\
\hline
\end{tabular}


HNF-2935, Rev ()

Figure 2.1 296-P-16 Ventilation System.

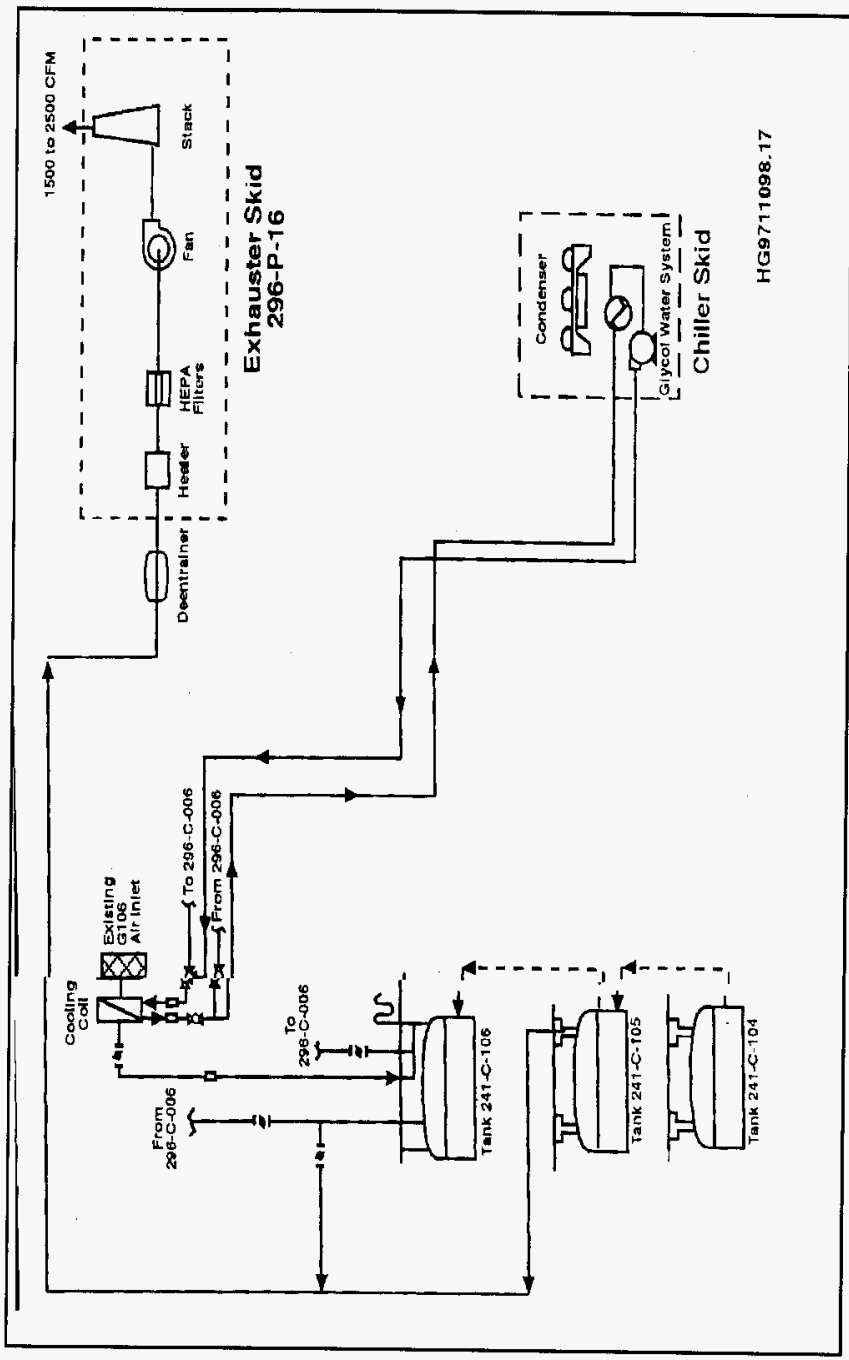


HNF-2935, Rev 0

Figure 2.2 296-C-(006 Ventilation System.

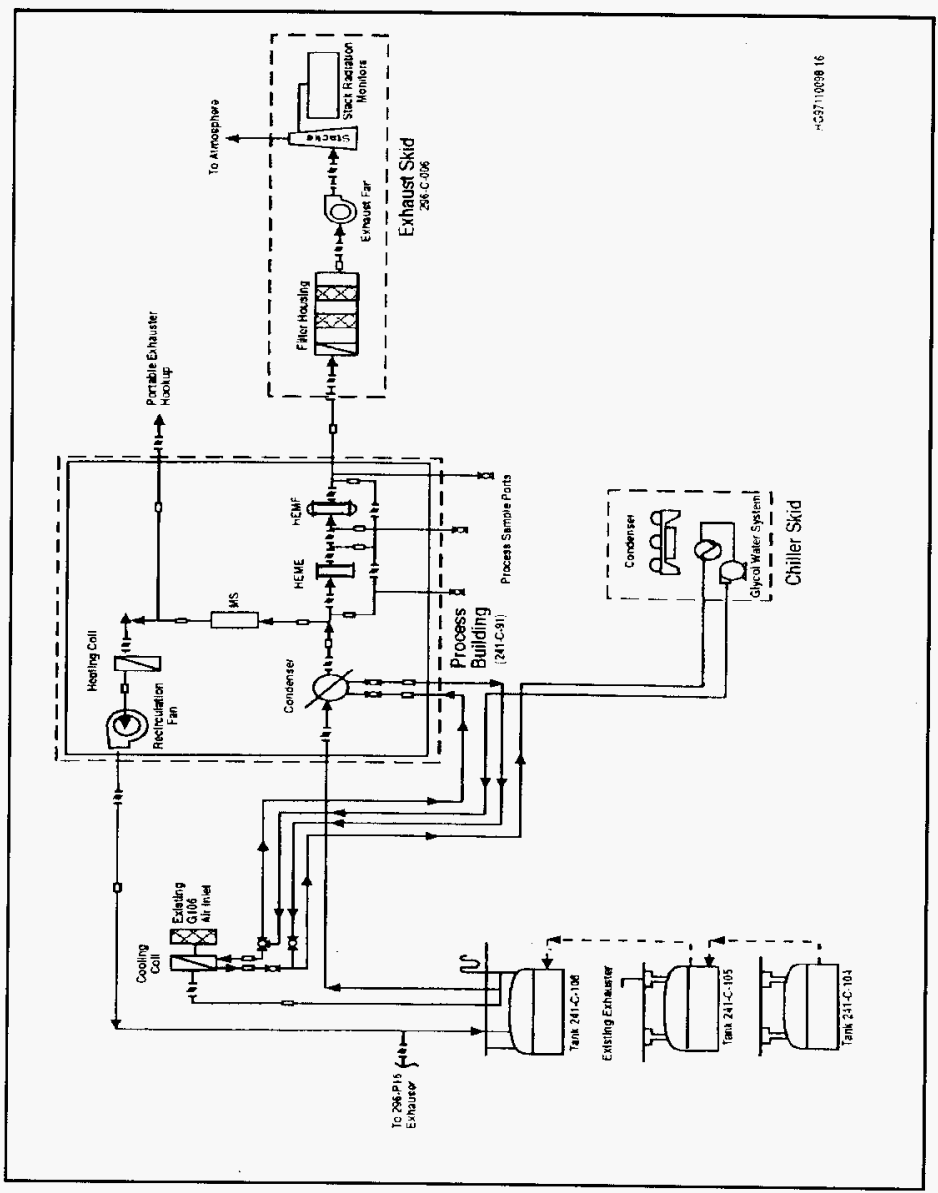


HNF-2935, Rev ()

Figure 2.3 Flammable Gas Test Hydrogen Concentration.

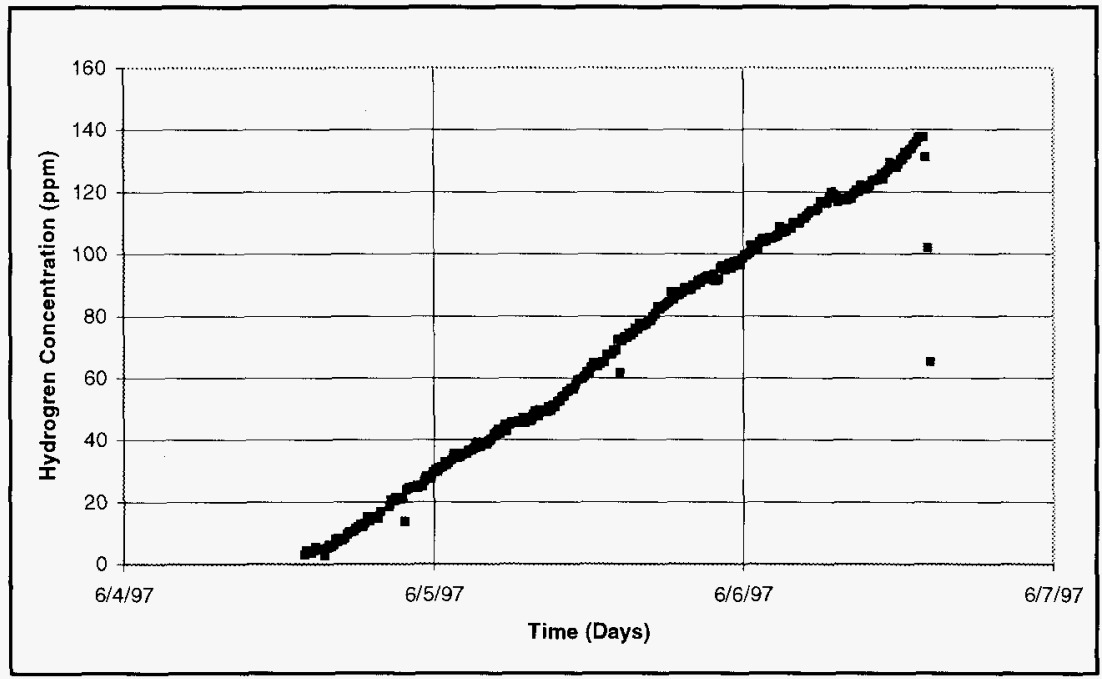


HNF-2935, Rev 0

Figure 2.4 Dome Space Temperature During Flammable Gas Tests.

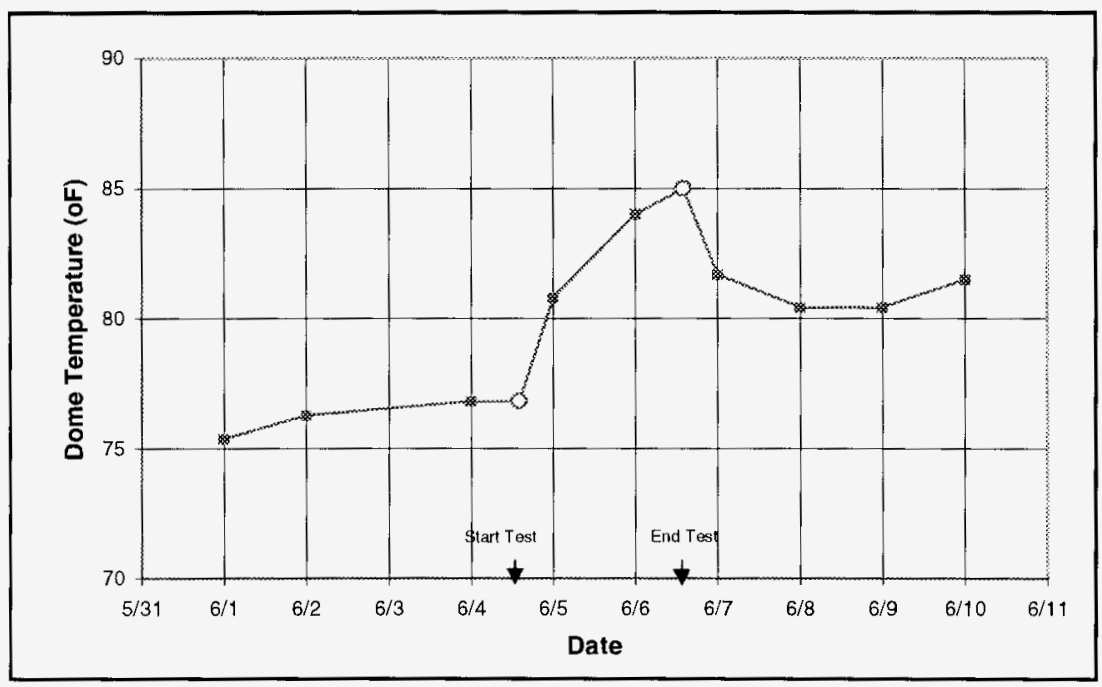


HNF-2935, Rev 0

Figure 2.5 Dome Temperatures For The 1992 C-106 Ventilation Outage.

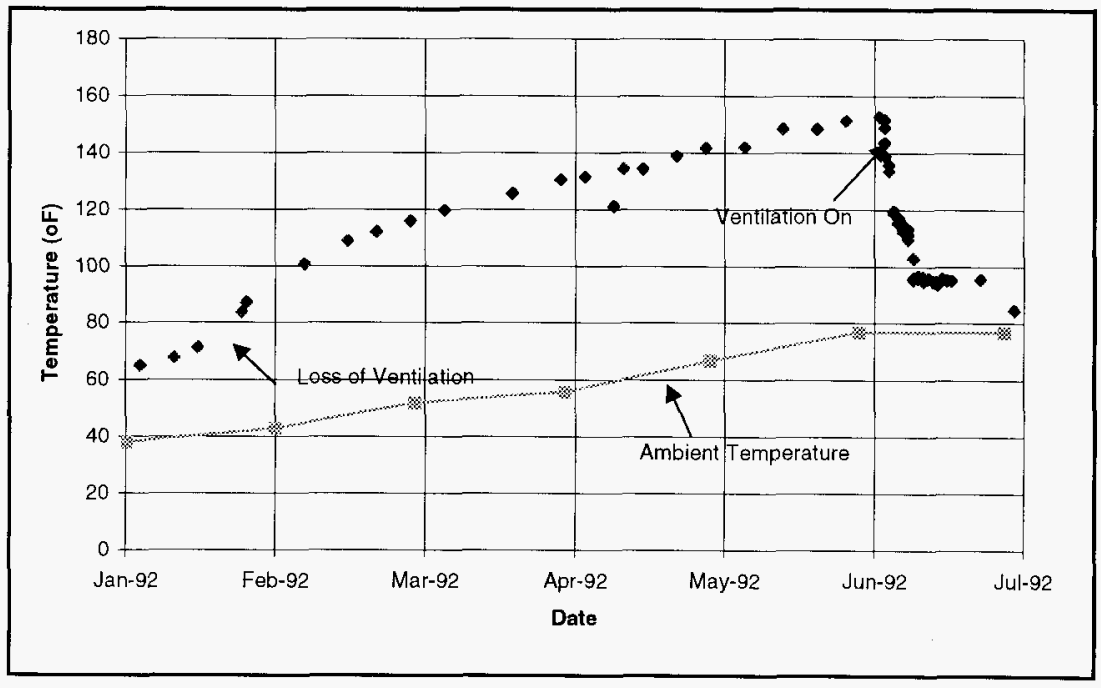


HNF-2935, Rev 0)

Figure 2.6 Waste Tank Soil Conductivity.

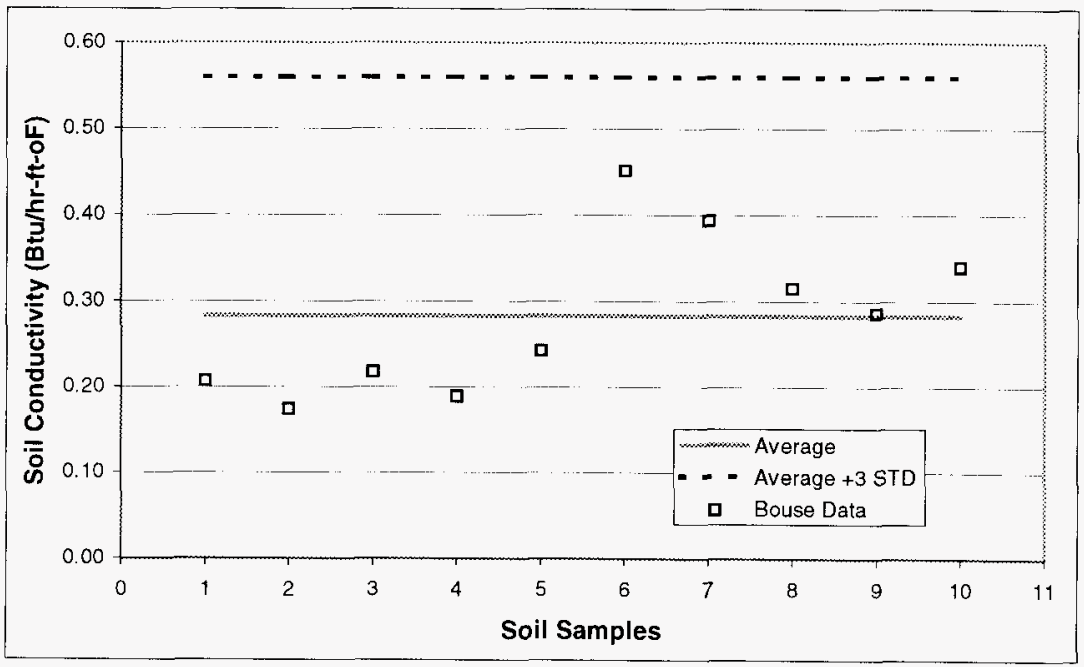




\section{HNF-2935, Rev 0}

\subsection{THERMAL HYDRAULIC MODELS}

Three thermal hydraulic models were developed for the evaluation of the $296-\mathrm{C}-1006$ system. The GOTH computer code ${ }^{1}$ was used to model the hydraulic characteristics of the 296 P-16 and 296-C-(006 ventilation systems. The GOTHIC computer code ${ }^{2}$ was used to model the passive breathing rates for Tank 241-C-106. The models are described in the following sections.

The GOTH code is a proprictary computer code ol John Marvin, Inc. It is a multidimensional, multi-phase, finite difference, thermal hydraulic computer code which has been applicd extensively to the analysis of waste tanks. This code is particularly suited for modeling both Tank 241-C-106 and Tank 241-AY-102 because of it's mechanistic treatment of the pool evaporation and capability to include actual meteorological data boundary conditions (temperature, pressure and humidity). The GOTH code includes standard one dimensional heat conduction models used to model the soil and waste conduction. The GOTH computer code is similar to GOTHIC (George 1995). GOTH was derived from the GOTHIC code by adding the non-Newtonian physics required to model the waste fluid flow. Both computer codes have been used extensively for thermal hydraulic analysis for both single and double shell waste tanks and have been benchmarked against tank data (Sathyanarayana 1996).

\subsection{6-P-16 HVAC SYSTEM GOTH MODEL}

The GOTH model of the 296-P-16 ventilation system is shown in Figure 3.1. The tank dome spaces are modeled as lumped parameter volumes. The tank waste is not included because the model is intended only to model the hydraulic characteristics of the ventilation system. Volumetric fan components are used to set tank flows to those measured during the ventilation tests (Section 2.3.1). The volumetric fans are connected to pressure boundary conditions, which are identified as 10P and 11P in Figure 3.1.

The Tank 241-C-106 inlet is modeled with three pressure boundary conditions (9P, 8P, 2P), three flow paths representing the three inlet filters $(10,11,12)$ and an inlet volume (4). The inlet filters were modeled as laminar flow devices. The actual filter flow areas and path length werc used for the flow path. The hydraulic diameter was then set to provide the pressure drop characteristics established by the filter manufacturer. The flow resistance was 0.4 inches water gauge pressure drop for a $360 \mathrm{~cm}$ flow (Palazzolo 1996). A hydraulic diameter of $0.003 \mathrm{ft}$. provided the correct pressure drop. The two inlet filters for Tank 241-C-105 were modeled in the

\footnotetext{
${ }^{1}$ GOTH is a registered trademark of John Marvin, Inc.

${ }^{2}$ GOTHIC is a registered trademark of the Electric Power Research Institute
} 


\section{HNF-2935, Rev 0}

same fashion. The same hydraulic diameter was used for the single breather filter for Tank 241 C-104, using the smaller dimensions of the filter.

The three tanks are connected by overflow or cascade lines, which were modeled as flow paths 1 and 2. Leak paths were modeled for each tank. The leak paths were modeled as orifices with a loss coefficient of 2.7 using flow paths $(3,4,6)$ and pressure boundary conditions (1P, 3P, 5P). The leak areas for Tanks 241-C-I05 and 106 were determined from the ventilation flow data presented in Section 2.3.1. The leak area of Tank 241-C-104 was assumed to be the same as Tank 241-C-105.

\subsection{6-C-006 HVAC SYSTEM GOTH MODEL}

The 296-C-006 ventilation system was modeled with GOTH similar to the 296-P-16 ventilation system model. A schematic of the model is shown in Figure 3.2 Active ventilation is provided only to Tank 241-C-106. The ventilation flow is modeled with a volumetric fan component (1Q) and a pressure boundary condition (6P). The Tank 241-C-106 inlet tilters are isolated for the 296-C-006 configuration and Tank 241-C-105 has a single smaller breathing filter. The filter model is the same as discussed in the previous section.

The tank leak paths are modeled with flow paths and pressure boundary conditions as described in the previous section. The leak areas determined from the C Farm Ventilation Flow Test, were used in this model.

The 296-C-(0)6 ventilation system includes a re-circulation loop, which was discussed in Section 3.2. The objective of the evaluation of the 296-C-006 system, was to characterize the dome space pressure for ventilation flows and assumed leak areas. Because the re-circulation loop draws suction and discharges into the dome space of Tank 241-C-106, it does not affect the dome space pressure, and therefore was not included in the model.

\subsection{PASSIVE BREATHING MODEL}

The Flammable Gas Process Test for Tank 241-C-106 was evaluated to determine the leak area for Tank 241-C-106 when the pump pits are sealed. This requires a passive breathing model since ventilation was eliminated during the process test. The Tank 241-C-106 1992 ventilation outage data was used to benchmark the passive breathing model. Figure 3.3 show a schematic of the GOTHIC passive breathing model for Tank 241-C-106. The dome space is modeled as a single lumped parameter model (Volume 1). The tank inlet modeling discussed in Section 3.1, was used to model the inlet filters and flow paths. These are shown in Figure 3.3 as boundary conditions $\mathrm{IP}, 4 \mathrm{P}$ and $5 \mathrm{P}$, flow paths $1,4,5,5$ and volume 4 . The leak path is shown as flow path 7 and boundary condition 2P. It is connected to a lumped parameter volume (5) which 


\section{HNF-2935, Rev ()}

represents a pump pit. All pressure boundary conditions used temperature and relative humidity data from the Hanford Meteorological Station (HMS). This HMS data was obtained from the World Wide Web (WWW) site terrassa.pnl.gov:2080/HMS.

Other boundary conditions included fluid boundary condition $3 \mathrm{~F}$, which provides makeup water for evaporation and fluid boundary condition $6 \mathrm{~F}$, which simulates the steady release of hydrogen.

The waste is modeled with two one-dimensional heat conductors ( 1 and 3 ). Conductor 1 represents the $40 \%$ of the waste and conductor 3 the remaining $60 \%$ of the waste. The conductors used the best estimate thermal parameters specified in Ogden 1998. The heat conductors are used only to provide the heat to the dome space for the passive breathing evaluation.

The soil near the tank bottom and sides was modeled with one dimensional soil conductors ( 4 and 5) which connect the to the bottom of the waste conductors ( 1 and 3 ) through dummy volume 2 and 3 . The ambient temperature boundary conditions are used for the other end of the soil conductors. The soil on top the tank was modeled with conductor 2 . Previous two dimensional modeling of Tank 241-C-106 (Thurgood 1995) found that approximately 10 to $15 \%$ of the tank heat was conducted through the soil. The actual soil depth was used for soil conductor 2. However, the length of conductors 4 and 5 were adjusted to provide the over all heat loss through the soil. The soil conductivity discussed in Section 2.3.5 was used for the soil conductors. 
HNF-2935, Rev 0

Figure 3.1 296-P-16 HVAC System GOTH Model.

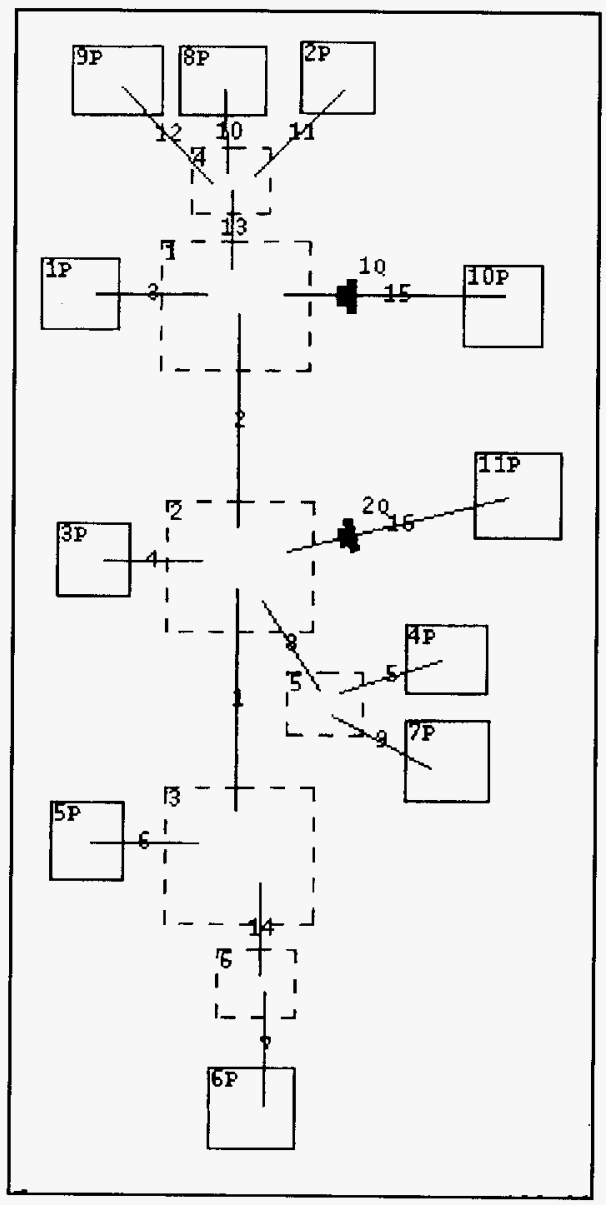


HNF-2935, Rev 0

Figure 3.2 296-C-006 HVAC System GOTH Model.

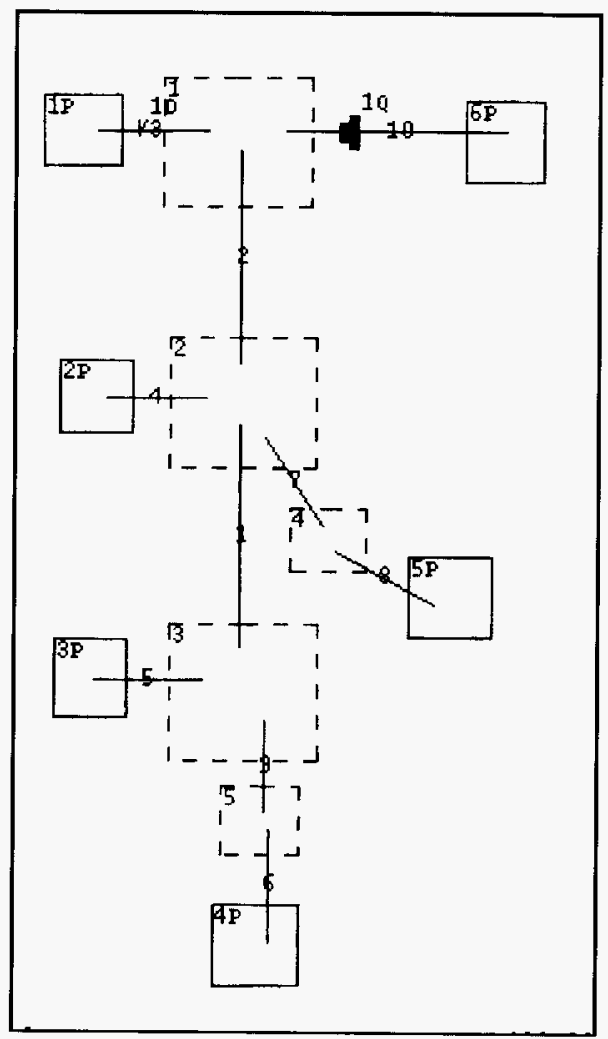


HNF-2935, Rev 0

Figure 3.3 Tank 241-C-106 Passive Breathing GOTHIC Model,

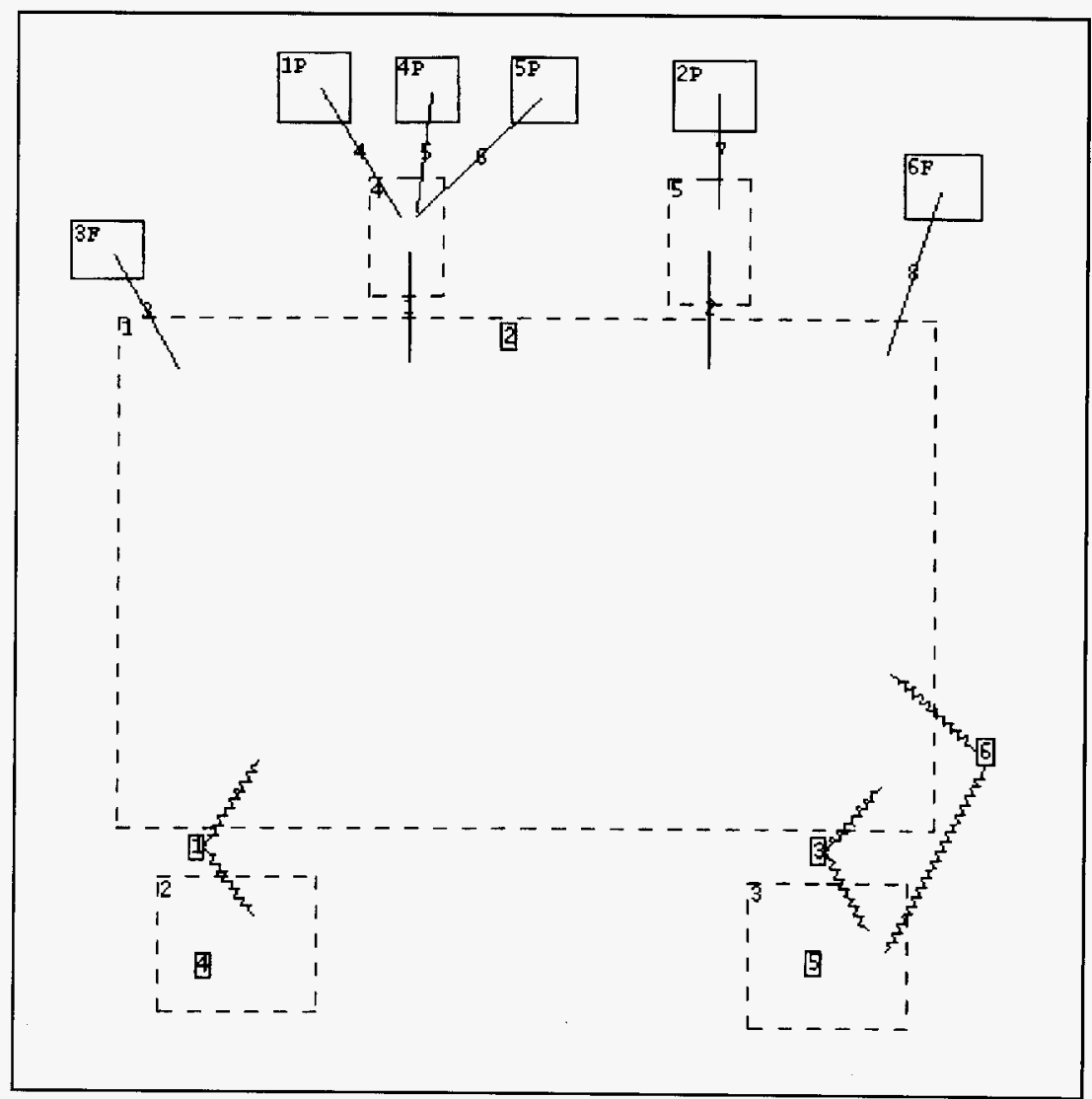




\section{HNF-2935, Rev 0}

\section{4.() THERMAL HYDRAULIC MODEL BENCHMARK}

The GOTH 296-P-16 model discussed in Section 3.1 was benchmarked using C Farm ventilation flow data. This provided validation for the model and provided for a determination of the lcak flow areas for Tank 241-C-105 and 106. The 296-C-006 model was derived from the 296-P-16 model and did not require separate bench marking. The passive breathing model (Section 3.3) used to evaluate the Flammablc Gas Process Test, was benchmarked with data from Tank 241-C-106, during the 1992 ventilation outage. These benchmark analyses and the evaluation of the Flammable Gas Process Test are provided in the following sections.

\subsection{6-P-16 SYSTEM FLOW TESTS}

The ventilation flow data from the July 1997 flow tests for C Farm, were used to benchmark the GOTH model. This was then used to evaluate the 296-C-006 ventilation system. The data were also used to determine the sealed leak area for Tanks 241-C-105 and the unsealed leak area for Tank 241-C-106. Table 4. I shows the measured inlet and outlet flows (bold font), the inferred leak flows and the flow between tanks. GOTH analyses were performed using the model presented in Scction 3.1. The leak areas for Tank 241-C-106 and 105 were adjusted or provide the ratio of inlet filter to tank outlet flows, measured in the ventilation flow tests. Figure 4. 1 shows the predicted flows for Tank 241-C-106. A leak flow area of 95 square inches provided a good match with the data. The leak flow is just over $50 \%$ of the total tlow. The flow through the cascade line from Tank $241-\mathrm{C}-105$ is small, about $51 \mathrm{cfm}$. Table 4.1 also summarizes the flows for Tank 241-C-105 which are shown in Figure 4.2. A leak area of 8 square inches provides a good match with the ventilation flow data. The flow through the cascade line from Tank 241-C-104 is also small, approximately $47 \mathrm{cfm}$. The leak flow is just 18 $\%$ of the total flow. During the Ventilation Flow Test, the pump pits in Tank 241-C-106 were unsealed while the pump pits for Tanks 241-C-104 and 105 were scaled. This is evident from the leak areas required to match the flow test data and the flow split between inlet flow and leak flow.

The predicted flows for Tank 241-C-104 are shown in Table 4.1. Most of the $47 \mathrm{cfm}$ drawn from the tank, comes through the leak path rather than the small breather filter. Although the leak area was assumed to be the same as Tank 241-C-105, this introduces little uncertainty in the leak area estimates since the flow from Tank 241-C-104 is small compared to the ventilation flow. The friction loss assumed for the leak flow were based upon an orifice loss coefficient (Section 3.1). This represents a mininum loss coefficient. This loss may be higher resulting in lower estimates for the leak areas. Thus the estimated leak areas are conservative relative to the estimate of dome space pressure. Thus the actual leak area for the sealed pump pits of Tank 241C-105 may be less than 8 square inches. 
HNF-2935, Rev 0

Table 4.1 Summary of Flows for 296-P-16 System Flow Test.

\begin{tabular}{|c|c|c|c|c|c|c|}
\hline $\begin{array}{c}\text { Tank } \\
\text { Identification }\end{array}$ & $\begin{array}{c}\text { Inlet Filter } \\
\text { Flow } \\
\text { (CFM) }\end{array}$ & $\begin{array}{c}\text { Leak Flow } \\
\text { (CFM) }\end{array}$ & $\begin{array}{c}\text { C-105 } 10 \text { C-106 } \\
\text { Cascede } \\
\text { Line Flow } \\
\text { (CFM }\end{array}$ & $\begin{array}{c}\text { C-104 } 10 \text { C-105 } \\
\text { Cascade Line } \\
\text { Flow } \\
\text { (CFM) }\end{array}$ & $\begin{array}{c}\text { Ventilation } \\
\text { Outlet } \\
\text { Flow } \\
\text { (CFM) }\end{array}$ & $\begin{array}{c}\text { Leak Area } \\
\text { (In })^{2}\end{array}$ \\
\hline 241-C-106 & $\mathbf{1 3 3 7}$ & 1443 & 51 & & $\mathbf{2 8 3 1}$ & 95 \\
\hline $241-$ C-105 & $\mathbf{4 3 8}$ & 107 & 51 & 47 & $\mathbf{5 4 1}$ & 8 \\
\hline 241-C-104 & 6 & 41 & & 47 & 0 & 8 \\
\hline
\end{tabular}

\subsection{VENTILATION OUTAGE}

The passive breathing feature of the GOTHIC model presented in Section 3.3, was benchmarked with the 1992 ventilation outage data from Tank 241-C-106. The model predicted the passive breathing rates, evaporation rates and dome space temperatures. The unsealed leak area for Tank 241-C-106 determined from the 1997 Ventilation Flow Tests, was used in the analyses. Monthly averaged Hanford Site meteorological data for temperature and humidity, were used for the analyses.

The predicted passive breathing rate during the ventilation outage is shown in Figure 4.3. The passive breathing rate increases about $85 \mathrm{cfm}$ as the dome space temperature increases. Figure 2.5 shows that the ambient temperature begins to increase, which decreases the density difference between dome spacc and ambient air. This reduces the driving force for passive breathing which results in the decreasing flow shown is Figure 4.3. The dome space temperature increases with the increasing ambient temperature, approximately two months after the loss of ventilation. This near constant temperature differential results in a passive breathing rate of just over $80 \mathrm{~cm}$ shown in Figure 4.3.

A comparison of the predicted dome space temperatures and measured temperatures are shown in Figure 4.4. The dome temperatures during the ventilation outage are predicted reasonably well by the GOTHIC model. This is an indication that the passive breathing rates shown in Figure 4.3 are also reasonable, since the dome space temperature is strongly dependent upon the evaporative cooling provided by the passive breathing flow. This analysis demonstrates that the GOTHIC passive breathing model can predict the natural convection llows in the tank dome space and this can provide an assessment of the Flammable Gas Process Test in Tank 241C-106. 


\section{HNF-2935, Rev 0}

\subsection{TANK 241-C-106 FLAMMABLE GAS PROCESS TEST}

In June of 1997, a Flammable Gas Process Test was conducted for Tank 241-C-106 to determine the steady state flammable gas release in the tank. The pump pits for the tank were sealed prior to the test. The rate of increase in flammable gas concentration is a function of the natural convection or passive breathing, which is dependent upon the leak area. Therefore the data can be used to determine the sealed leak area Tank 241-C-106. The GOTHIC model, which was benchmarked with the 1992 ventilation outage data (Section 4.2), was used for the evaluation.

Figurc 4.5 shows a comparison with the predicted hydrogen concentration and actual tank measured concentrations in the Tank 241-C-106 dome space assuming unsealed pump pits. The passive breathing rate should be significantly higher than the breathing rate for sealed pump pits. This is seen in Figure 4.5. The predicted hydrogen concentration is significantly lower than the measured data as a result of the predicted passive breathing rate of over $20 \mathrm{cfm}$. Thus the unsealed leak area determined from the Ventilation Flow Tests (95 square inches), results in a passive breathing rate significantly larger than that inferred from the flammable gas data.

Figure 4.6 shows a comparison of the measured and predicted liquid temperatures during the process test. The breathing rates are too low to provide significant cooling. Thus, the dome temperature during the short process test is not sensitive to the leak area.

Figure 4.7 shows the predicted hydrogen concentration in Tank 241-C-106 for a leak area equivalent to the sealed pump leak area for Tank 241-C-105. This leak area is a result of sealing the Tank 241-C-105 pump pits. The predicted hydrogen concentration is still lower than the actual measured data. This indicates that the assumed leak area is larger than the actual leak area of Tank 24 I-C-106 during the flammable gas tests.

Figure 4.8 shows the predicted hydrogen concentration in Tank $241-\mathrm{C}-106$ with an assumed leak area of 1 square inch. There is close agreement with the measured hydrogen concentration. This indicates that the pump pits in Tank 241-C-106 were essentially sealed, resulting in a very small passive breathing rate $(2 \mathrm{cfm})$. This demonstrates the effectiveness of pump pit sealing for Tank 24l-C-106.

It is unlikely that the pump pits for Tank $241-\mathrm{C}-106$ were sealed more tightly than the pits in Tank 241-C-104 and Tank 241-C-105. The later tanks have been sealed with several inches of urethane material and protective silicon paint. The pump pits in Tank 241-C-106 during the process test were sealed with sealed by taping. The higher estimated leak area for Tank $241-\mathrm{C}$ 105 is probably the result of uncertainties in the measured flows or the conservative estimate for the leak path loss coefficient. 
HNF-2935, Rev 0)

Figure 4.1 Tank 241-C-106 Flows for 296-P-16 HVAC System.

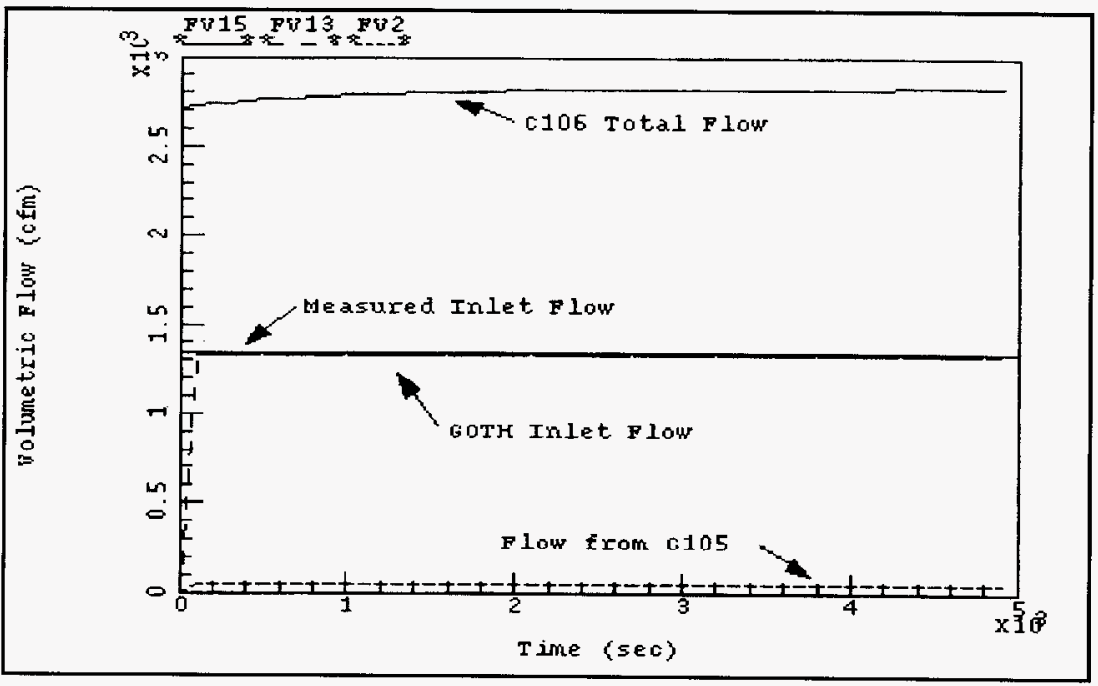


HNF-2935, Rev 0

Figure 4.2 Tank C-105 Flows for 296-P-16 HVAC System.

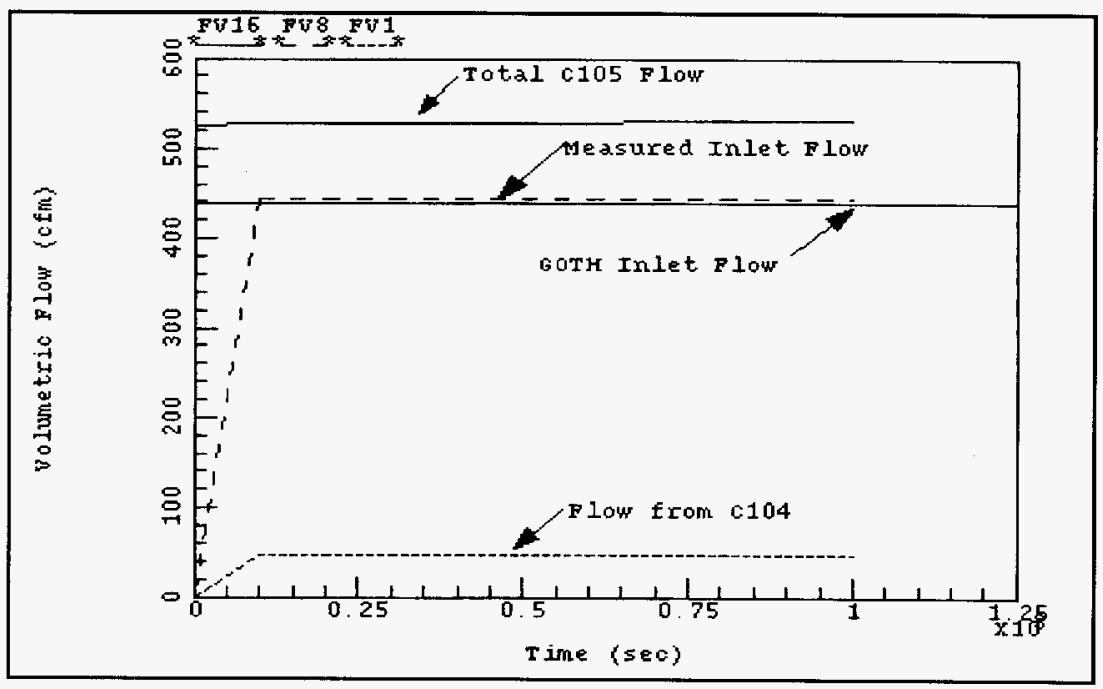


HNF-2935, Rev 0

Figure 4.3 Predicted Passive Breathing Rate for Tank 241-C-106 Ventilation Outage.

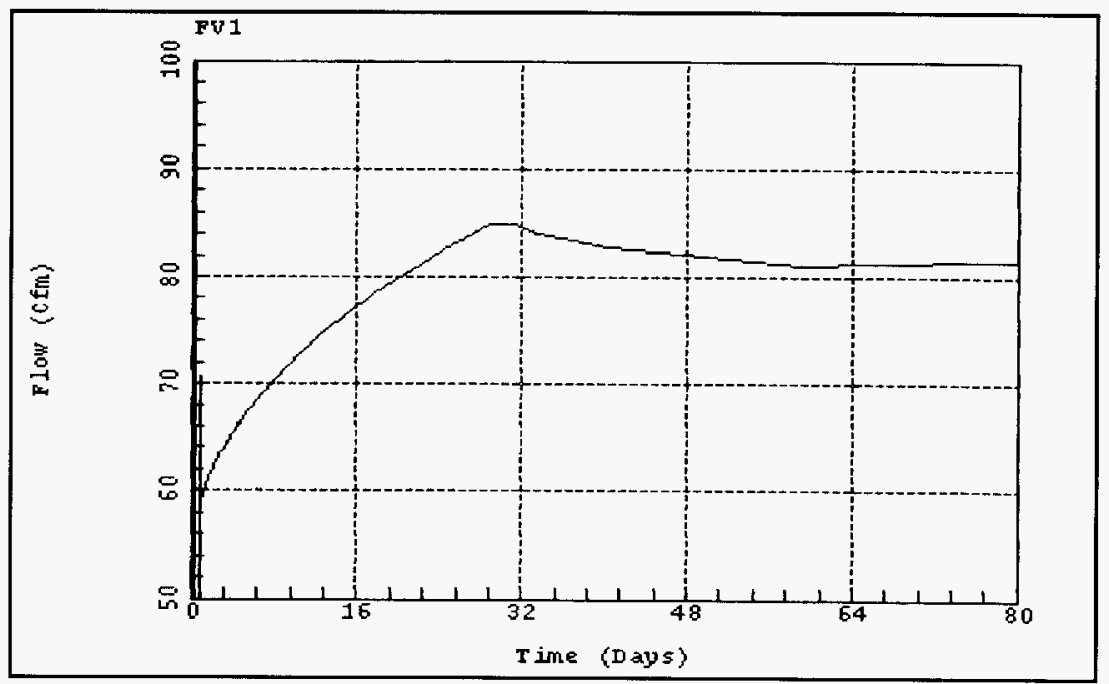


HNF-2935, Rev 0

Figure 4.4 Dome Space Temperature Comparison for 1992 Ventilation Outage.

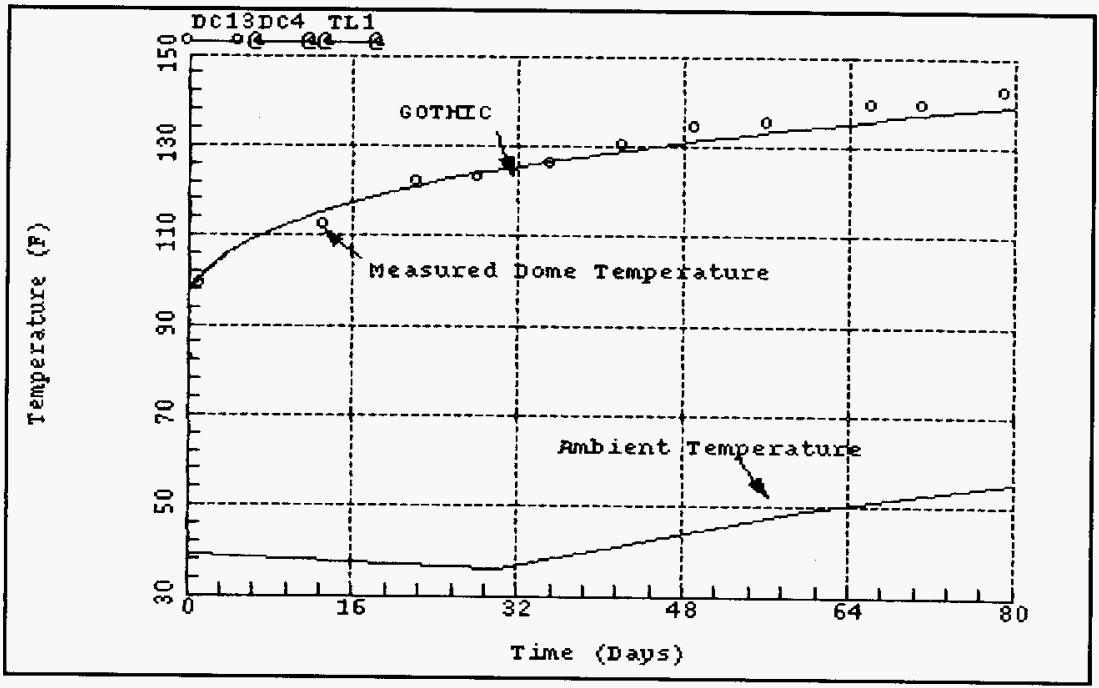


HNF-2935, Rev 0

Figure 4.5 Predicted Hydrogen Concentration for Unsealed Pump Pits.

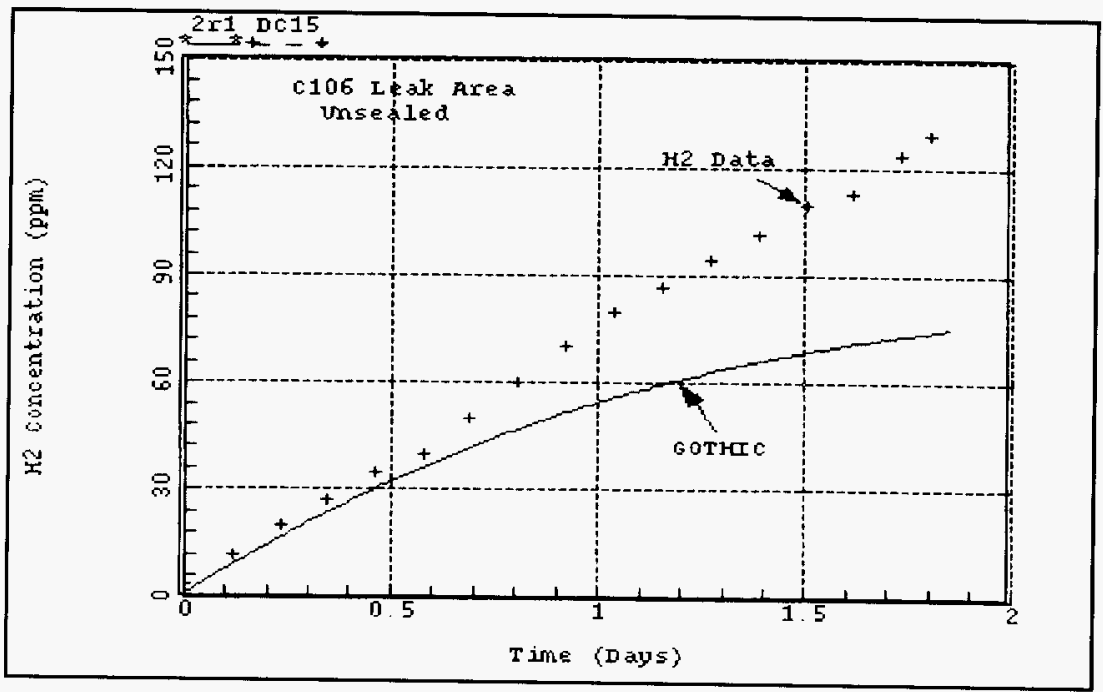


HNF-2935, Rev 0

Figure 4.6 Comparison With Flammable Gas Test Dome Space Temperature.

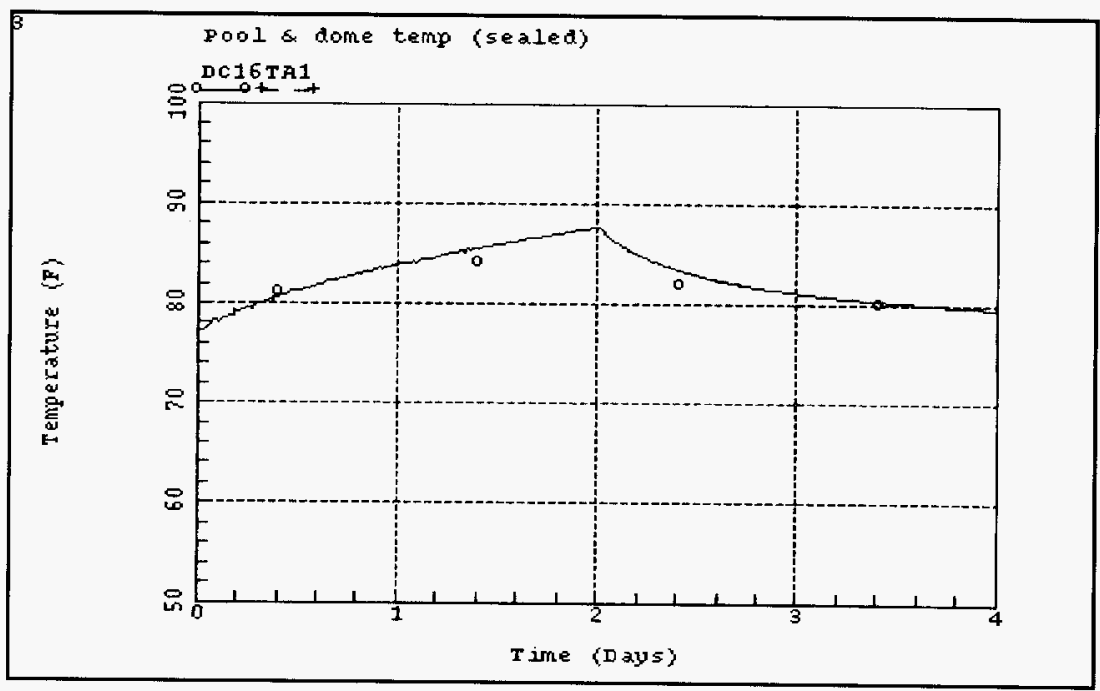




\section{HNF-2935, Rev 0}

Figure 4.7 Hydrogen Concentration for Tank 241-C-105 Leak Area.

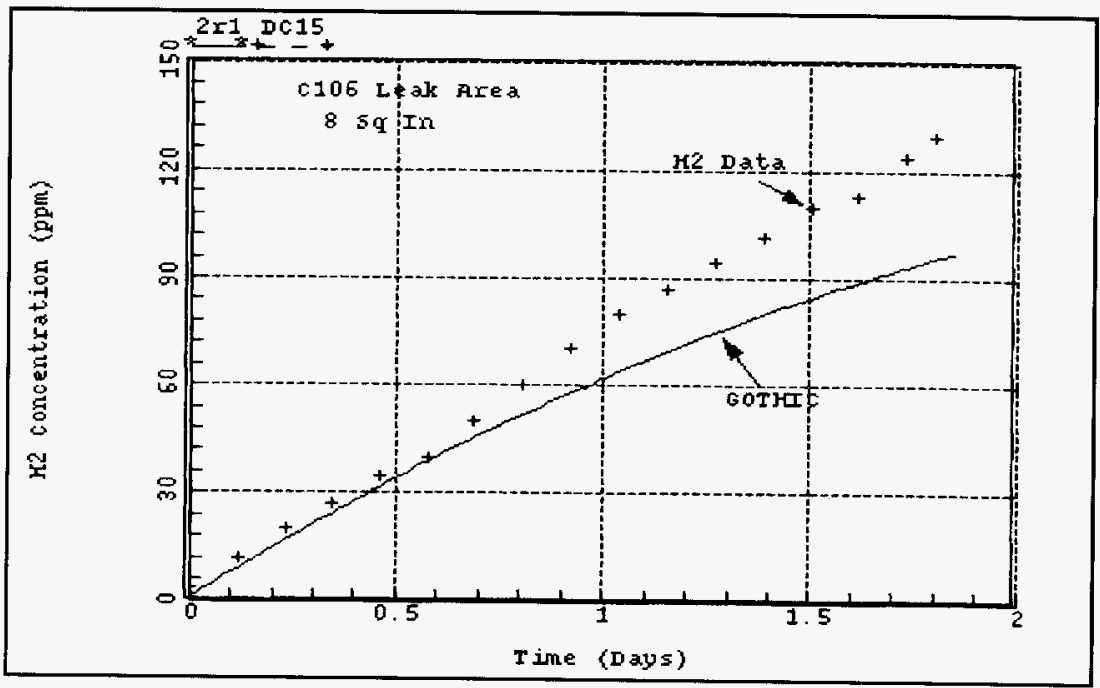


HNF-2935, Rev 0

Figure 4.8 Hydrogen Concentration for Sealed Pump Pits in Tank 241-C-106.

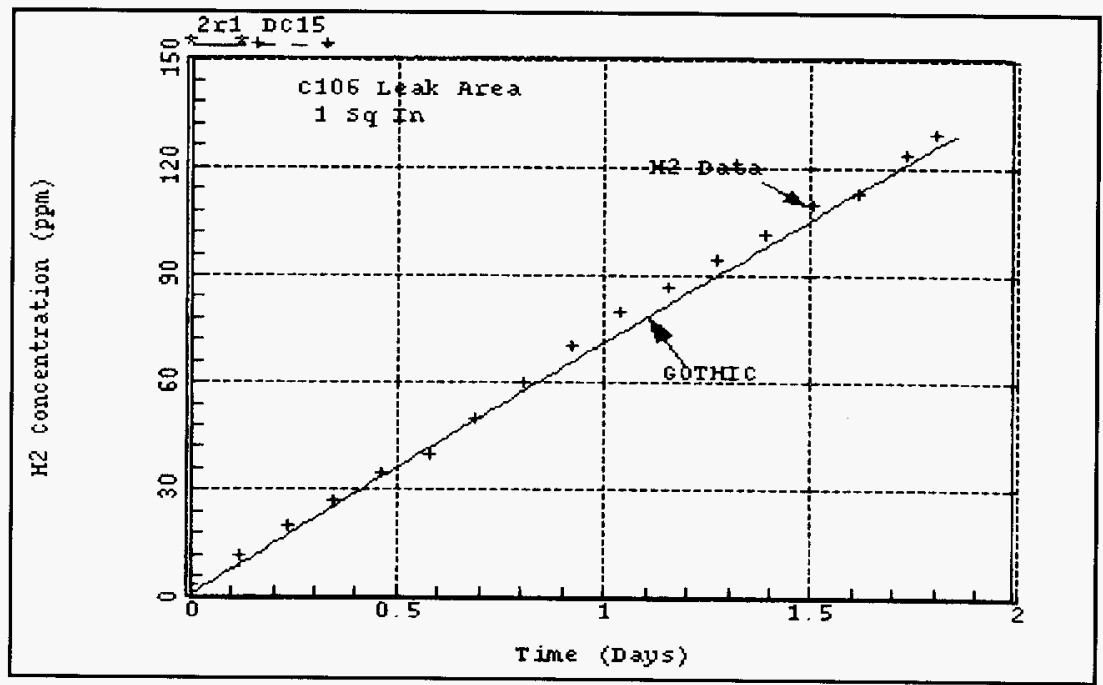


HNF.2935, Rev 0

\subsection{SYSTEM 296-C-(006 EVALUATION}

The benchmarked GOTH model was used to evaluate the flow and pressure behavior of the 296-C-(006 ventilation system. The evaluation was performed for a range of exhaust flows up to a maximum of $360 \mathrm{ctm}$. The leak area for Tank $241-\mathrm{C}-106$ was varicd parametrically and included the unscaled leak area and Tank 241-C-105 leak area determined from the 1997 flow tests and the sealed leak area determined from the 1997 Flammable Gas Process Test.

\subsection{TANK 241-C-106 UNSEALED PUMP PITS}

Table 5.1 shows the predicted tank tlows for a Tank $241-\mathrm{C}-106$ exhaust flow of 360 ctm. The pump pits in Tank 241-C-106 were assumed to be unsealed (95 square inches). Most of the tlow into Tank 241-C-106 comes from the leak flow. Only $15 \mathrm{cfm}$ comes from Tank 241-C-105 through the cascade line. The inlet filter filters are eliminated for the 296-C-006 ventilation system configuration (See Figure 3.2).

Table 5.1 Summary of Flows for 296-C-006 HVAC System with Unsealed Leak Area.

\begin{tabular}{|c|c|c|c|c|c|c|}
\hline $\begin{array}{c}\text { Tank } \\
\text { Identification }\end{array}$ & $\begin{array}{c}\text { Inlet Filter } \\
\text { Flow } \\
\text { (CFM) }\end{array}$ & $\begin{array}{c}\text { Leak Flow } \\
\text { (CFM) }\end{array}$ & $\begin{array}{c}\text { C-105 to C-106 } \\
\text { Cascade } \\
\text { Line Flow } \\
\text { (CFM }\end{array}$ & $\begin{array}{c}\text { C-104 to C-105 } \\
\text { Cascade Line } \\
\text { Flow } \\
(\text { CFM })\end{array}$ & $\begin{array}{c}\text { Ventilation } \\
\text { Outlet } \\
\text { Flow } \\
\text { (CFM) }\end{array}$ & $\begin{array}{c}\text { Leatk Area } \\
\left(\mathrm{In}^{2}\right)\end{array}$ \\
\hline $241-\mathrm{C}-106$ & - & 345 & 15 & 360 & 95 \\
\hline $241-\mathrm{C}-105$ & 4 & 8 & 15 & 3 & 0 & 8 \\
\hline $241-\mathrm{C}-104$ & $<<1$ & 3 & & 3 & 0 & 8 \\
\hline
\end{tabular}

\subsection{LEAK AREA PARAMETRIC}

Table 5.2 shows the predicted tanks flow rates for an 296-C-006 exhaust flow of $360 \mathrm{cfm}$ and a Tank 241-C-106 leak area of 8 square inches corresponding to the leak area of Tank 241C-105. The leak flow is significantly lower than the unsealed pump pit. Nearly $33 \%$ of the flow comes from Tank 241-C-105 through the cascade lines. 
HNF-2935, Rev 0

Table 5.2 Summary of Flows for 296-C-(006 HVAC System with C-105 Leak Area.

\begin{tabular}{|c|c|c|c|c|c|c|}
\hline $\begin{array}{c}\text { Tank } \\
\text { Identification }\end{array}$ & $\begin{array}{l}\text { Inlet Filter } \\
\text { Flow } \\
(\text { CFM) }\end{array}$ & $\begin{array}{l}\text { Leak Flow } \\
\text { (CFM) }\end{array}$ & $\begin{array}{c}\text { C-105 to C-106 } \\
\text { Cascade } \\
\text { Line Flow } \\
\text { (CFM }\end{array}$ & $\begin{array}{c}\text { C-104 to C-105 } \\
\text { Cascade Line } \\
\text { Flow } \\
\text { (CFM) }\end{array}$ & $\begin{array}{l}\text { Ventilation } \\
\text { Outles } \\
\text { Flow } \\
\text { (CFM) }\end{array}$ & $\begin{array}{c}\text { Leak Area } \\
\left(\operatorname{In}^{2}\right)\end{array}$ \\
\hline $241-C-106$ & ---- & 240 & 120 & ----- & 360 & 8 \\
\hline $241-C-105$ & 68 & 37 & 120 & 15 & ---- & 8 \\
\hline $241-C-104$ & 1 & 14 & & 15 & ----- & 8 \\
\hline
\end{tabular}

Table 5.3 shows the predicted tanks flows for a 296-C-(006 exhaust flow of $360 \mathrm{cfm}$ and a leak area for Tank 241-C-106 of one square inch, which corresponds to the sealed pump pit leak area during the 1997 Flammable Gas Tests. Only about $15 \%$ of the flow comes from leak flow. The remainder comes from Tank 241-C-105 through the cascade line.

Table 5.3 Summary of Flows for 296-C-016 HVAC System with Sealed Pump Pit.

\begin{tabular}{|c|c|c|c|c|c|c|}
\hline $\begin{array}{c}\text { Tank } \\
\text { Identification }\end{array}$ & $\begin{array}{c}\text { Inlet Filter } \\
\text { Flow } \\
\text { (CFM) }\end{array}$ & $\begin{array}{c}\text { Leak Flow } \\
\text { (CFM) }\end{array}$ & $\begin{array}{c}\text { C-105 to C-106 } \\
\text { Cascade } \\
\text { Line Flow } \\
\text { (CFM }\end{array}$ & $\begin{array}{c}\text { C-104 to C-105 } \\
\text { Cascade Line } \\
\text { Flow } \\
\text { (CFM) }\end{array}$ & $\begin{array}{c}\text { Ventilation } \\
\text { Outlet } \\
\text { Flow } \\
\text { (CFM) }\end{array}$ & $\begin{array}{c}\text { Leak Area } \\
\left(\text { In }^{2}\right)\end{array}$ \\
\hline $241-$ C-106 & $\cdots$ & 53 & 307 & $\cdots$ & 360 & 1 \\
\hline $241-$ C-105 & 211 & 68 & 307 & 28 & -- & 8 \\
\hline $241-$ C-104 & 3 & 25 & & 28 & $-\cdots$ & 8 \\
\hline
\end{tabular}

The tank tlows and Tank 241-C-106 dome vacuum are summarized in Table 5.4 for the three cases presented in Tables 5.1 through 5.3. The table shows that the dome space vacuum for Tank 241-C-106 is less than the desired 0.3 Inches W.G. if the pump pits in Tank 241-C-106 are unsealed. Clearly the pits must be sealed to achieve the desired vacuum. When the pits are sealed at least as wcll as Tank 241-C-105, the dome vacuum increases to an acceptable level of over 1 Inch W.G. When the pump pits in Tank 241-C-106 are highly sealed as indicated by the 1997 Flammable Gas Process Test, a high dome vacuum can be achicved. 
HNF-2935, Rev 0

Table 5.4 Summary of Flows and Dome Vacuum for 296-C-006 HVAC System.

\begin{tabular}{|c|c|c|c|c|c|c|c|c|}
\hline $\begin{array}{c}\mathrm{Cl}(06 \\
\text { Leak } \\
\text { Ared } \\
\text { (Sq Inch) }\end{array}$ & $\begin{array}{c}\mathrm{Cl} 06 \\
\text { Vacuum } \\
\text { (In W.G.) }\end{array}$ & $\begin{array}{l}\text { Clo6 } \\
\text { Leak } \\
\text { Flow } \\
\text { (CFM) }\end{array}$ & $\begin{array}{l}\text { Clog } \\
\text { Caseade } \\
\text { Flow } \\
\text { (CFM) }\end{array}$ & $\begin{array}{c}\mathrm{Cl}(05 \\
\text { Inlet } \\
\text { Filler } \\
\text { Flow } \\
\text { (CFM) }\end{array}$ & $\begin{array}{l}\text { Cl05 } \\
\text { Leak } \\
\text { Flow } \\
\text { (CFM) }\end{array}$ & $\begin{array}{c}\text { C105 } \\
\text { Cascade } \\
\text { Flow } \\
\text { (CFM) }\end{array}$ & $\begin{array}{l}\text { ClO4 } \\
\text { Inlet } \\
\text { Filter } \\
\text { Flow } \\
\text { (CFM) }\end{array}$ & $\begin{array}{c}\text { Clo4 } \\
\text { Leak } \\
\text { Flow } \\
\text { (CFM) }\end{array}$ \\
\hline 95 & 0.02 & 346 & 14 & 1 & 10 & 3 & .1 & 2.9 \\
\hline 8 & 1.2 & 242 & 118 & 23 & 67 & 28 & 3 & 25 \\
\hline 1 & 7.2 & 49 & 311 & 103 & 145 & 63 & 14 & 49 \\
\hline
\end{tabular}

Figure 5.1 shows the predicted dome space vacuum for Tank 241-C-106 for a 296-C-006 flow rate of 300 and $360 \mathrm{cfm}$. If the Tank 241-C-106 pump pits are sealed, as well as Tank 241C-105, acceptable vacuum can be achieved for exhaust flows of $300 \mathrm{ctm}$ or less. Figure 5.2 shows the same information with an expanded scale.

\subsection{OPERATIONAL CONSIDERATIONS}

Complete sealing of the pump pits may not he possible or even desirable. Operational considerations may require a small leak flow to eliminate condensation problems or issues related the operation of the Tank 241-C-106 equipment. It is recommended that Tank 241-C-106 be sealed as tightly as possible and then carefully controlled leak paths be provided, as needed to address equipment operation issues. 


\section{HNF-2935, Rev 0}

Figure 5.1 Tank 241-C-106 Vacuum Pressure for Leak Area Variation.

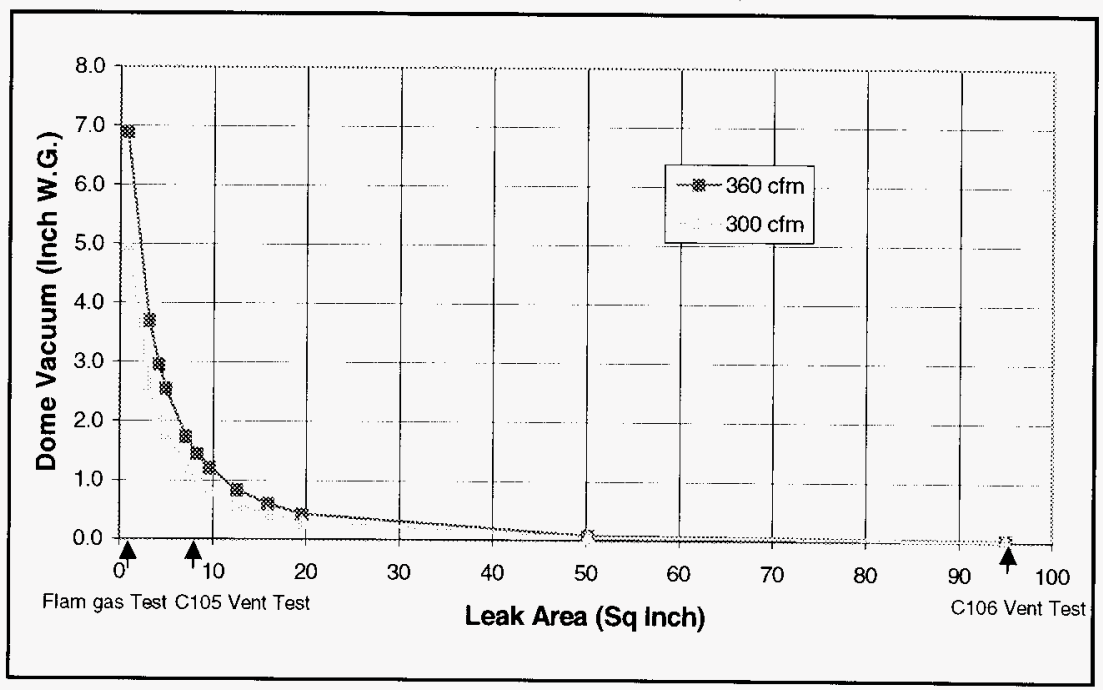


HNF-2935, Rev 0

Figure 5.2 Tank 241-C-106 Vacuum Pressure (Expanded Scale).

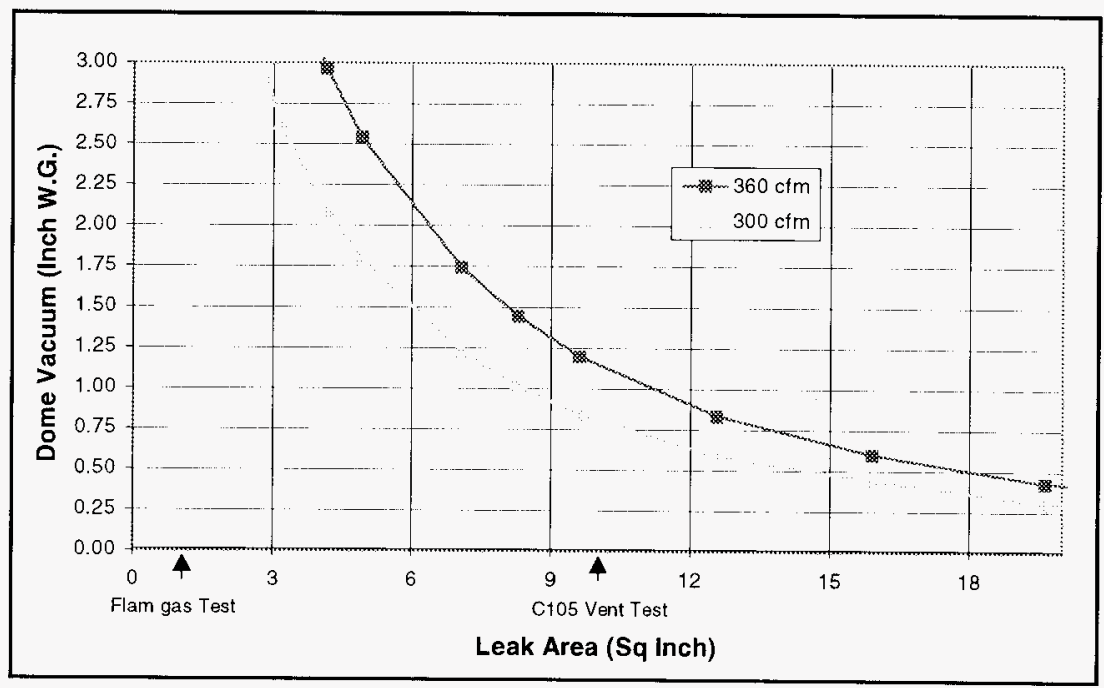




\section{HNF-2935, Rev 0)}

\subsection{CONCLUSIONS}

- The 296-C-1006 Ventilation System, with exhaust flows in the range of 300 to 360 ctin, will result in acceptable Tank 241-C-106 dome vacuums (>0.75 inches W.G.) with pump pit sealing for Tank 241-C-106.

- The pump pits for Tank 241-C-106 must be scaled to the same level as the conservative estimate for the pump pits in Tank 241-C-105 ( 8 square inches) to achieve the desired dome pressure with the 296-C-0066 ventilation system.

- System 296-C-006 tlows lower than 300 cfm can be accommodated if the pump pits in Tank 241-C-106 are sealed to the level indicated by the 1997 Flammable Gas Process Test. 


\section{HNF-2935, Rev 0}

\subsection{REFERENCES}

Bailey, J. W., 1998, C106 Tank Process Ventilation Test, HNF-SD-W320-ATR-()12, Numatec Hanford Company, Richland, Washington.

Bander, T. J., 1993, Revised Thermal History of Tank 241-C-106, WHC-SD-WM-ER-200, Westinghouse Hanford Company, Richland, Washington.

Bander, T.J., 1995, Tank 241-C-106 Process Test Report, WHC-SD-WM-ER-427, Westinghouse Hanford Company, Richland, Washington.

Bouse 1975, Thermal Conductivity of Hanford Waste Tank Solids and SX Tank Farm Soil Samples, ARH-CD-378, Atlantic Richfield Hanford Company, Richland, Washington.

Carothers, K. G. and e1.al., 1998, Tank 241-C-106 Waste Retrieval Sluicing System Process Control Plan, HNF-SD-WM-PCP-()13, Flour Daniel Hanford, Richland. Washington.

George, Thomas L., et. al., 1995, GOTHIC Containment Analyses Package User Manual, NAI 8907-(12 Rev 6, Numerical Applications, Inc., Richland, Wa.

Lohrosbi 1998, Ventilation Balance Data, Personal Communications with Cognizant Engineer for DST Ventilation Systems, June 15, 1998.

Ogden, D. M. and K. Sathyanarayana, 1998, Project W-320 SAR and Process Control thermal Analyses, HNF-SD-W320-ER-(004, Rev 1, Numatec Hanford Company, Richland, Washington.

Palazzolo 1996, Installation, Operating and Maintenance Manual for Exhaust Skid Ventilation Unit, K(0701-10M, Ellis \& Watts, Batavia, Ohio.

Thurgood, M. J. and ct. al., 1995, GOTH Tank C-106 Thermal Hydraulic Analysis Related to the 1994 Process Test, NAI-940708-4, Numerical Applications Inc. for Westinghouse Hanford Company, Richland, Washington.

Sathyanaryana, K., and B. C. Fryer, 1996, Evaluation of Potential and Consequences of Steam Bump in High Heat Waste Tanks and Assessment and Validation of GOTH Computer Code, WHC-SD-WM-CN-022, Rev 0. Westinghouse Hanford Company, Richland, Washington. 
HNF-2935, Rev 0

APPENDIX A. Tank 241-C-106 CHILLER PERFORMANCE

A-I 


\section{HNF-2935, Rev 0}

\section{A-1.0 INTRODUCTION}

\section{A-1.1 PURPOSE}

The Project W-320 Process Control Plan (PCP) (Carothers 1998), requires that Tank 241C-106 be cooled to near winter conditions by operating the 296-P-16 Ventilation System inlet chiller (sce Figure 3.1). Chiller operation for Tank 241-C-106 was initiated June 30, 1998. The purpose of this evaluation is to determine if winter conditions can be achicved in the waste by the end of September.

\section{A-1.2 SCOPE}

The PCP states that winter conditions are achieved in the waste, when the waste is cooled continuously until the temperature of thermocouple 1 on the Riser 8 thermocouple tree reaches $148^{\circ} \mathrm{F}$. This was the measured winter temperature at the time the requirement was first established in 1996. Several years have passed since the requirement was first established. The maximum waste temperature has decreased as a result of radio nuclide decay. This will reduce the required time for chiller operation to achieve the temperature limit of $148^{\circ} \mathrm{F}$.

\section{A-2.0 THERMAL HYDRAULIC MODEL}

The evaluation of 296-P-16 chilling system was performed with the GOTHIC computer code. A schematic of the model is shown in Figure A-2.1. This model is nearly the same as the GOTHIC model used for the passive breathing analyses presented in Sections 4.2 and 4.3. A comparison with Figure 3.3 reveals that the inlet filter model has been removed shown in Figure A-2.1. This portion of the model was not needed because the inlet and leak flows are specified directly, using the flow boundary conditions identified as $I F$ and $4 F$ in the figure. In addition, the tank outlet (flow path 2 ) is connected directly to the pressure boundary condition $2 \mathrm{P}$. For forced ventilation there is no need to model the density difference between the inlet riser and pump pits, which are signilicant for passive breathing. Therefore, the pump pit volume was climinated. Other features of the model are the same as the model discussed in Section 3.3 .

The W-320 PCP chiller system will provide $40{ }^{\circ} \mathrm{F}$ chilled air to the tank inlet. The chilled inlet air was modeled with the IF fluid boundary condition shown in Figure A-2.1. The leak flow through the pump pits was modeled with the $4 \mathrm{~F}$ fluid boundary condition shown in the ligure. Analyses were performed assuming both unsealed pump pits and sealed pump pits. The flow split between inlet filter flow and leak flow, presented in Table 2.1, was used for the analyses. A nominal flow of $2300 \mathrm{cfm}$ was assumed for the once-through ventilation.

Figure A-2.2 shows the monthly average ambient temperature data obtained from the 


\section{HNF-2935, Rev 0}

Hanford Meteorological Station. This provides the temperature boundary condition for nonchilled air. Weckly average temperatures were used for the month of July during the chiller operation. Figure A-2.2 shows that the peak July average temperature for 1998 was higher than the previous four years. Daily temperatures reached $112^{\circ} \mathrm{F}$. This will be discussed in the next section.

Similar monthly data was used for the relative humidity. However, the thirty year average monthly values were used for the relative humidity up to January of 1998. Monthly average values were used from January 1998 through June of 1998 and weekly average values for July 1998.

The chiller system was activated on June 30, 1998. The analyses assumed a start date of July 1,1998 with continuous operation. 
HNF-2935, Rev 0

Figure A-2.1 GOTHIC Tank 241-C-106 Model.

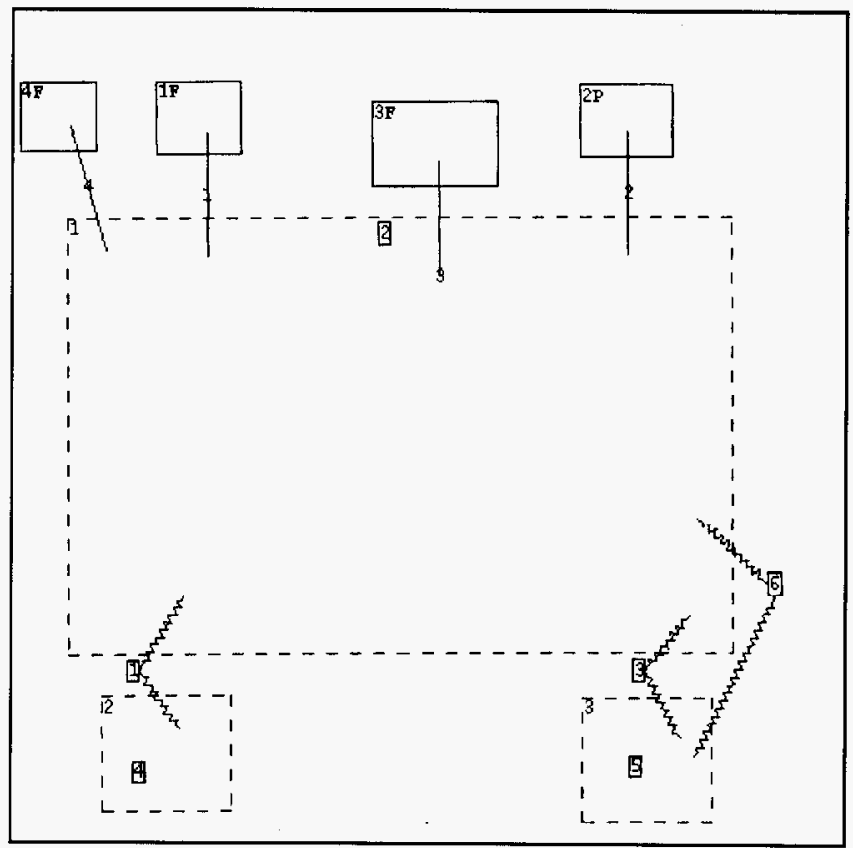

A-4 
HNF-2935, Rev ()

Figure A-2.2 Monthly Average Ambient Temperature Data.

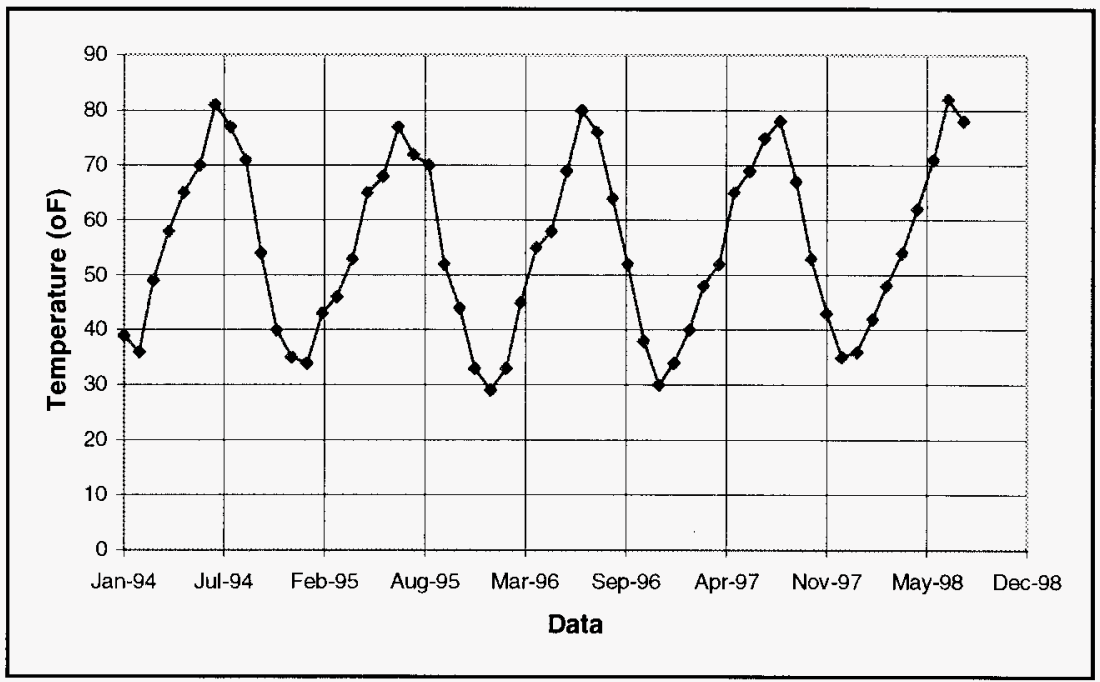




\section{HNF-2935, Rev ()}

\section{A-3.0 EVALUATION OF CHILLER}

The purpose of the evaluation was to determine if the temperature criteria established by the PCP will be met with the operation of the 296-P-16 chiller system. Analyses were performed from January 1, 1994 through September 30, 1998. Tank cooling was initiated on July 1, 1998. The extent to which the pump pits have been sealed was unknown at the time of the analyses. Therefore, two bounding cases were considered. The first made the conservative assumption that the pump pits were unsealed, with about $50 \%$ of the llow entering the tank through pump pit leak paths. This air is not cooled prior to entering the dome space. A second bounding case assumed that the pits were entirely sealed, with all the inlet air passing through the inlet cooling coils. A third case was analyzed which assumed no chiller operation. This provided a basis for assessing the effectiveness of the chiller operation.

\section{A-3.1 CHILLER OPERATION WITH UNSEALED PUMP PITS}

The first analyses assumed unsealed pump pits with about $50 \%$ of the inlet air chilled by the 296-P-16 system. Figure A-3.1 shows a comparison of the dome space and Riser 8 Thermal Couple (TC) 1 data, with the GOTHIC predictions. Riser 8, TC 1 data is the basis for the PCP temperature criteria. Riser 8 does not represent the maximum waste temperatures, but is the most reliable temperature measurements available for the waste. The analyses included the time period from January 1, 1994. However, the Tank 241-C-106 1994 Process Test resulted in anomalous temperalure behavior (Bander 1995). The data from January 1, 1994 to January 1, 1996 was therefore not used for the present evaluation. Figure A-3.1 shows reasonable agreement with the dome space and waste temperature data. The annual temperature cycles are evident from the figure. The effect of the chiller operation is clearly seen both in the dome space data and the GOTHIC analyses. The dome space air temperature immediately begins to cool. The dome space temperature data and GOTHIC begin to increase near the end of July as the ambient temperature increase to $112^{\circ} \mathrm{F}$. The analyses assumed typical monthly average data from August and September. As the ambient temperatures decrease, the chiller system becomes more effective and again begins to reduce the dome temperature. This trend is expected through the remainder of the chiller operation. The increase in dome temperature, alter the initiation of chiller operation, is an indication that:

1. The pump pits were not completely sealed which allowed un-cooled air to enter the tank dome. This had an observable effect as the ambient temperature increased to extreme levels.

2. As the ambient temperature increased, the Glycol Water System of the 296-P-16 ventilation system, was unable to chill the inlet air to the desired $40^{\circ} \mathrm{F}$. 


\section{HNF-2935, Rev ()}

If item 2 is the explanation, then the performance of the chiller should be significantly improved for the remainder of the chiller operation.

Figure A-3.2 shows the waste temperature at the location of the Riser 8 , TC 1. Also shown in the figure is the $148^{\circ} \mathrm{F}$ temperature criteria established by the PCP. Notice that the winter of 1995 temperature was $148^{\circ} \mathrm{F}$. This was the basis for the temperature limit set by the PCP to assure winter subcooling conditions in the waste. Due to radio nuclide decay, the winter temperatures continue to decrease. Notice that the maximum waste temperature in 1994 is significantly higher than the trend in the following data would predict. The minimum temperature in 1996 is also higher. This is the result of the 1994 Process Test. Figure A-3.3 shows predicted waste temperature at the location of Riser $8, \mathrm{TC} 1,1998$. The abscissa of the graph denotes the time in months after a January 1,1998. The figure demonstrates that the operation of the Tank 241-C-106 chiller, assuming unsealed pump pits, eliminates the normal seasonal increase in temperature and begins reducing the temperature to below the limit by the end of August, 1998.

Figure A-3.4 shows the waste temperature at the location of the maximum temperature. In summer of 1994, following the process test of that year, the temperature was predicted to reach waste saturation conditions (Thurgood, 1995). Radio nuclide decay has reduced the maximum annual temperature over $10^{\circ} \mathrm{F}$ since that time. Thus additional subcooling margin has been derived since the PCP temperature limit was first established. Figure A-3.4 shows that after chiller operations, assuming unsealed pump pits, the maximum waste temperature will be nearly $15^{\circ} \mathrm{F}$ below the saturation temperature ( $15^{\circ} \mathrm{F}$ subcooling). In fact the waste temperature will be only a few degrees above the saturation temperature at dome pressures.

\section{A-3.2 NO CHILLER OPERATION}

A second calculation was performed assuming no chiller operation. This analyses helps demonstrate the elfectiveness of the chiller operation during the month of July, 1998. The predicted dome spacc and waste temperatures (Riser 8, TC 1) are shown in Figure A-3.5. The difference in measured and predicted dome space temperatures, after actual chiller operation hegan in Tank 241-C-106, can clearly be seen in the figure. The predicted dome space temperature increases significantly during the period of maximum temperatures in July, 1998.

A comparison of the predicted waste temperature at the location of Riser 8, TC 1 and the PCP temperature criteria, is shown in Figure A-3.6. Without chiller operation, the wastc temperature would well exceed the temperature limit. A comparison of Figures A-3.2 and A-3.6 clearly show the elfectiveness of the chiller operation during the month of July as ambient temperatures soared. 


\section{HNF-2935, Rev ()}

\section{A-3.3 CHILLER OPERATION WITH SEALED PUMP PITS}

A final analyses was performed assuming that the pump pits in Tank 241-C-106 were completely sealed at the initiation of chiller operation, and that the chiller system is capable of providing 40 "F chilled air to the tank inlet, regardless of the ambient air temperature. Since pump pits are expected to be sealed and ambient temperatures are dropping significantly, these assumptions are probably valid for the remainder of the chiller operation.

Figure A-3.7 shows the predicted and measured waste and dome space temperatures for this analysis. With the chiller system providing a constant $40^{\circ} \mathrm{F}$ inlet air temperature and no leak flow, the dome space temperature is not sensitive to the increasing July, 1998 ambient air temperalures. The dome temperature monotonically decreases to a minimum value.

The predicled waste temperature at the location of Riser $8, \mathrm{TC} 1$ is compared with the PCP temperature criteria in Figure A-3.8. The chiller operation with no leak flow and inlet air temperature at $40^{\circ} \mathrm{F}$ causes the waste temperature at Riser $8, \mathrm{TCl}$ to decrease immediately below the temperature limit. This indicates that when the pump pits in Tank 241-C-106 are sealed and the ambient temperatures decrease so that the chiller system can provide at least $40^{\circ} \mathrm{F}$ inlet air to the tank dome, the waste temperature will quickly decrease, meeting the temperature limit.

It should be noted that these analyses did not include the flow through the cascade line from Tank 241-C-105, which is not cooled. However, the analyses summarized in Table 4.1 of Section 4.1 shows that this flow is small compared with the ventilation flow and therefore not significant. 
HNF-2935, Rev 0

Figure A-3.1 Dome and Riser 8 Waste Temperature With Unsealed Pump Pit.

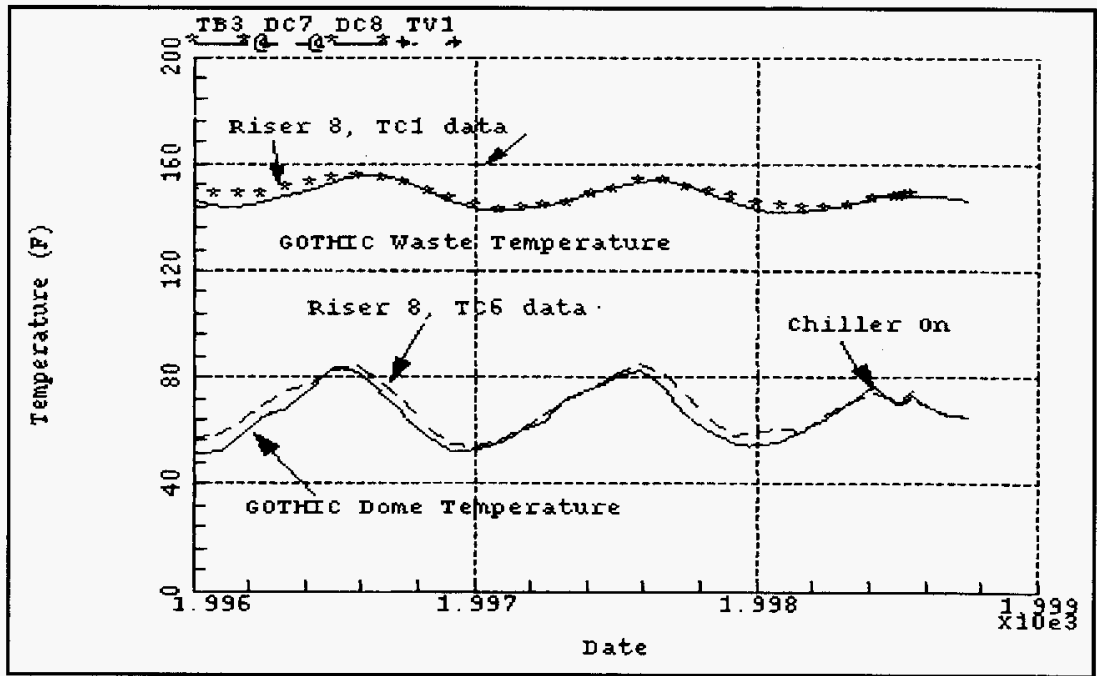


HNF-2935, Rev 1

Figure A-3.2 Comparison of With PCP Temperature Criteria With Unsealed Pump Pits.

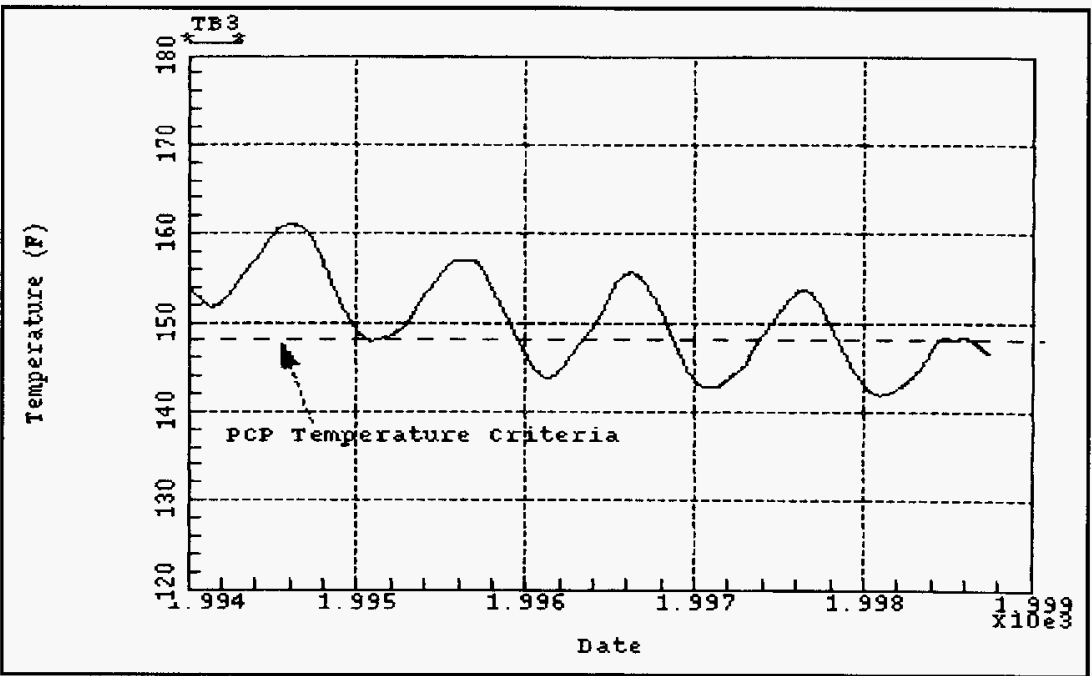


HNF-2935, Rev 0

Figure A-3-3 1998 Waste Temperature Comparison With Temperature Criteria, Unsealed.

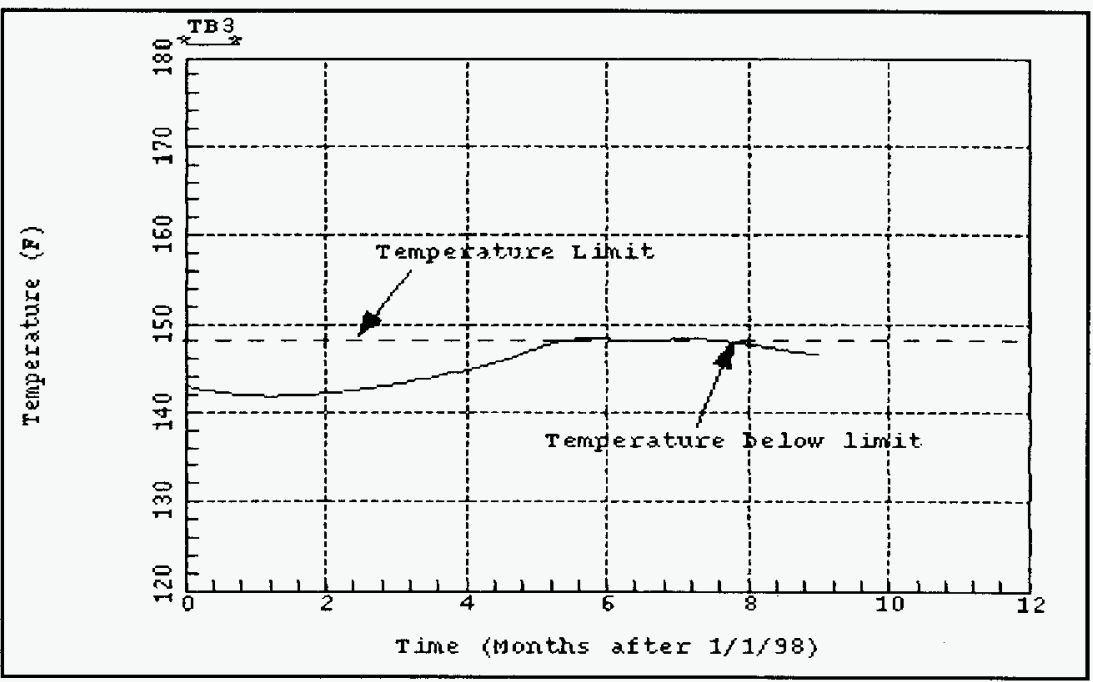

A- 11 
HNF-2935, Rev 0

Figure A-3.4 Maximum Waste Temperature With Unsealed Pump Pits.

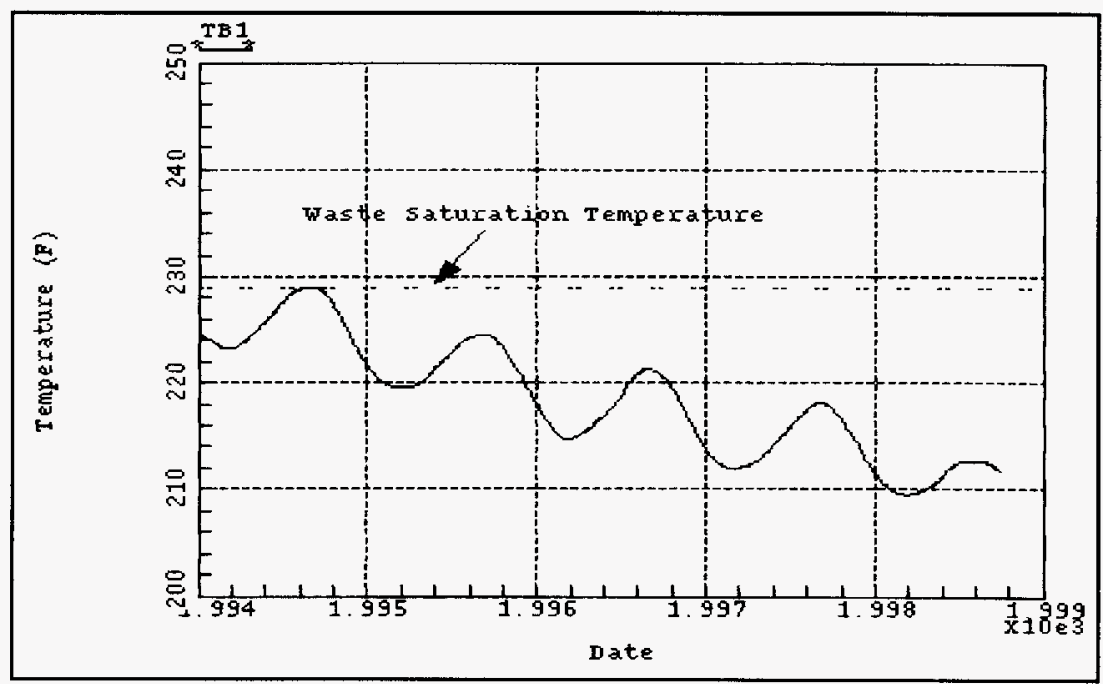


HNF-2935, Rev 0

Figure A-3.5 Dome and Riser 8 Waste Temperature With No Waste Chilling.

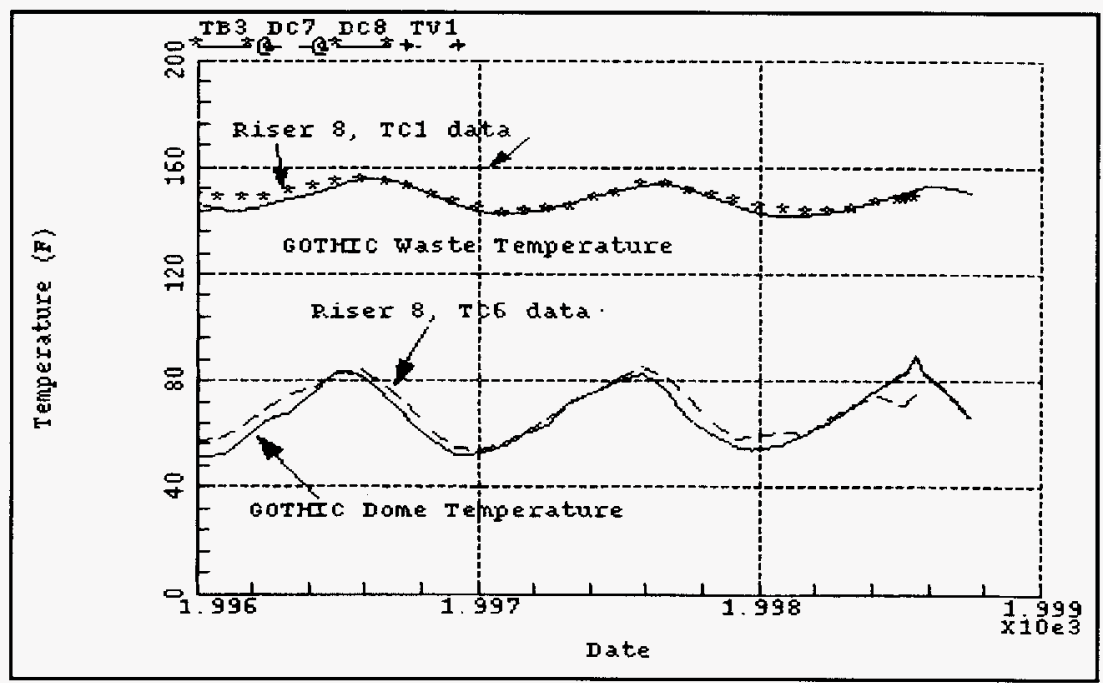


HNF-2935, Rev 0)

Figure A-3.6 Comparison With PCP Temperature Criteria With No Waste Chilling.

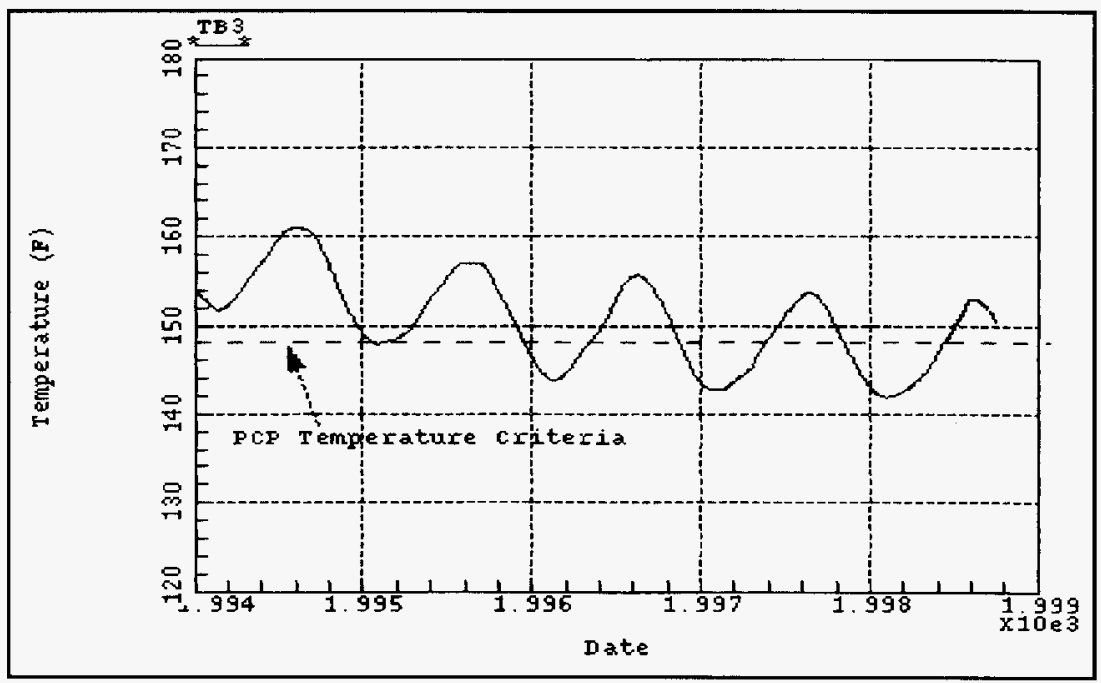


HNF-2935, Rev 0

Figure A-3.7 Dome and Riser 8 Waste Temperature With Sealed Pump Pits.

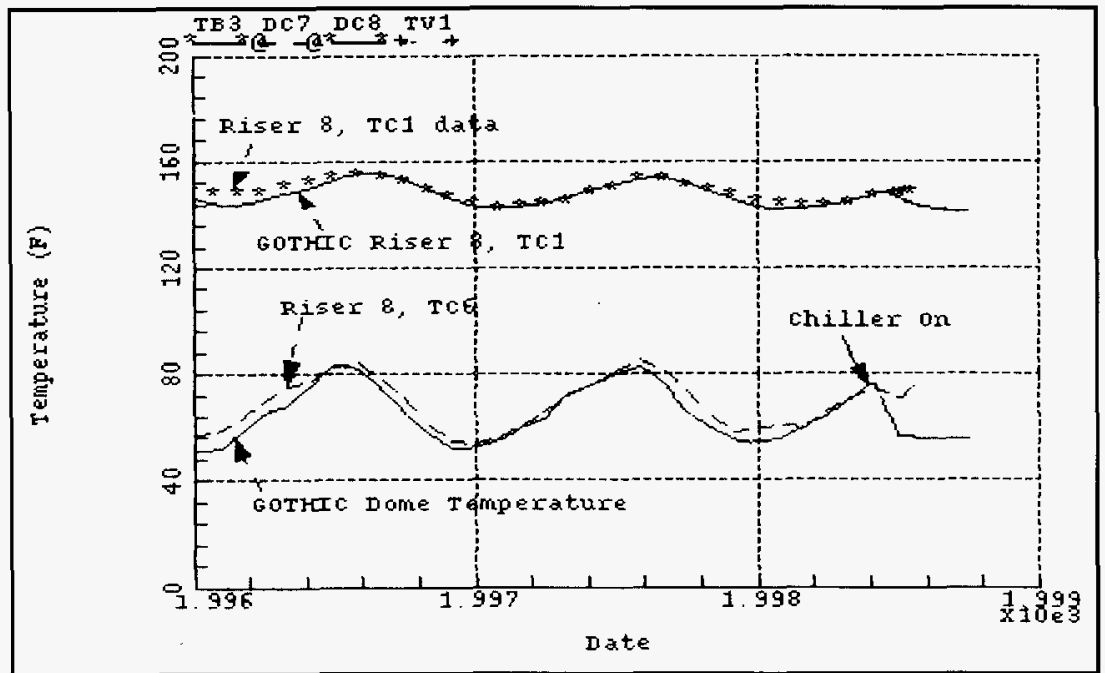

A- 15 
HNF-2935, Rev 0

Figure A-3.8 Comparison With PCP Temperature Criteria With Sealed Pump Pits.

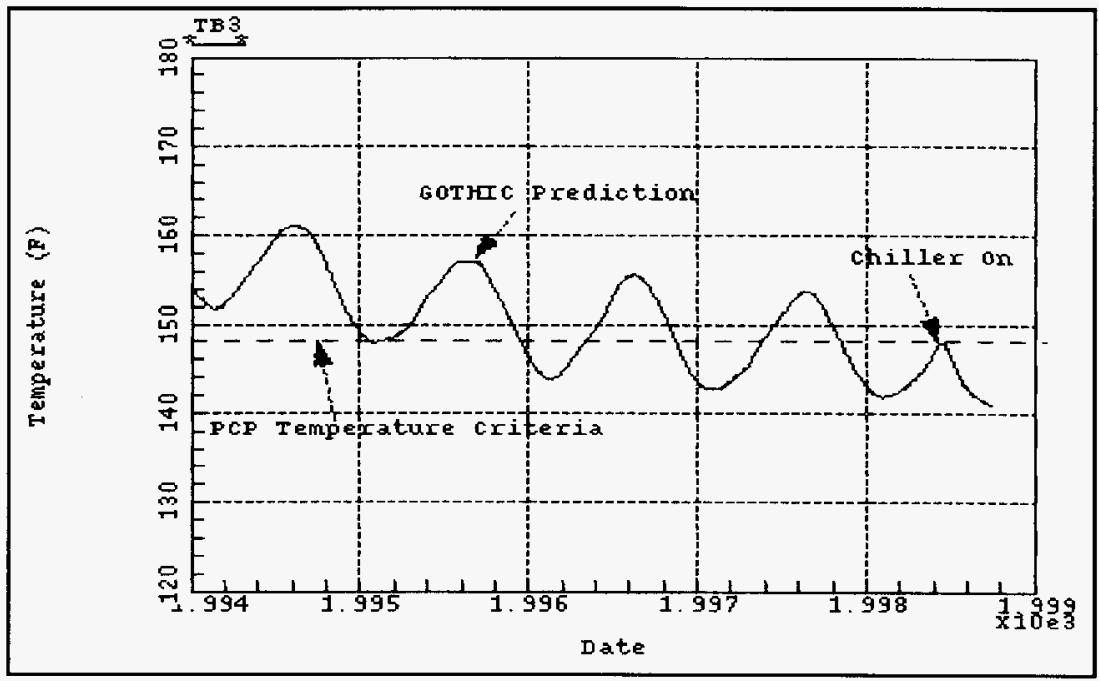




\section{HNF-2935, Rev 0)}

\section{A- 4.0 CONCLUSIONS}

- The continuous operation of the 296-P-16 ventilation system chiller from July 1, 1998 will reduce the Riser 8 , TC 1 waste temperatures below the PCP temperature limit of 148 'F by no later than September 1, 1998.

- Operation of the 296-P-16 ventilation system chiller with no (or very small) leakage inlet air, and maintaining the inlet air temperature at least $40^{\circ} \mathrm{F}$, will reduce the waste temperature below the PCP temperature criteria almost immediately.

- Radio nuclide decay, since 1994, has increased the subcooling margin in Tank 241-C-106 by nearly $10^{\circ} \mathrm{F}$. 
HNF-2935, Rev (

APPENDIX B. INFORMATION FOR QUALITY ASSURANCE RECORDS

B-1 
HNF-2935, Rev 0

The purpose of this appendix is to provide a listing of computer runs, spreadsheets and calculation notes which support the analyses presented in this report.

Table B.1 summarizes all computer runs. Table B.2 summarizes the spreadsheets and calculation notes.

Table B.1 Computer Analysis Files

\begin{tabular}{|l|c|c|l|}
\hline \multicolumn{1}{|c|}{ Case Description } & $\begin{array}{c}\text { Report } \\
\text { Figure\# }\end{array}$ & File Name & \multicolumn{1}{c|}{ Code Version } \\
\hline System 296-P-16 Benchmark & $4.1-4.2$ & P16bench & GOTH Version 3.4 \\
\hline 1992 Ventilation Outage Benchmark & $4.3-4.4$ & H2bencha & GOTHIC Version 5.0 \\
\hline H2 Process Test (95 sq inch leak area) & $4.5-4.6$ & H2pta & GOTHIC Version 5.0 \\
\hline H2 Process Test (8 sq inch leak area) & 4.7 & H2ptb & GOTHIC Version 5.0 \\
\hline H2 Process Test (1 sq inch leak area) & 4.8 & H2ptc & GOTHIC Version 5.0 \\
\hline 296-C-006 cvaluation & $5.1-5.2$ & Co06vent & GOTH Version 3.4 \\
\hline C-106 chiller evaluation (unsealed) & A-3.1 - A-3.4 & chiller & GOTHIC Version 5.0 \\
\hline C-106 chiller evaluation (no chilling) & A-3.5- A-3.6 & chillerb & GOTHIC Version 5.0 \\
\hline C-106 chiller evaluation (sealed) & A-3.7 - A-3.8 & chillerc & GOTHIC Version 5.0 \\
\hline Test filter model & N/A & FilterDP & GOTH Version 3.4 \\
\hline
\end{tabular}


HNF-2935, Rev 0

Table B.2 Supporting Calculation Notes and Spreadsheets

\begin{tabular}{|l|c|c|c|}
\hline \multicolumn{1}{|c|}{ Description } & $\begin{array}{c}\text { Report } \\
\text { Figure \# }\end{array}$ & File Name & Software Version \\
\hline $\begin{array}{l}\text { Soil conductivity data and results } \\
\text { from 296-C-006 parametric } \\
\text { analyses }\end{array}$ & $2.6,5.1-5.2$ & S980204-1 & EXCEL97 \\
\hline Flammable Gas Process Test Data & 2.3 & S980204-2 & EXCEL97 \\
\hline $\begin{array}{l}1992 \text { ventilation outage tank data } \\
\text { and met data }\end{array}$ & 2.5 & S980104-3 & EXCEL97 \\
\hline $\begin{array}{l}\text { Ambient temperature and humidity } \\
\text { and Tank 241-C-106 temperature } \\
\text { data }\end{array}$ & $\begin{array}{c}\text { A-2.2, A-3.1, } \\
\text { A-3.5, A-3.7 }\end{array}$ & S980204-4 & EXCEL97 \\
\hline $\begin{array}{l}\text { Tank 241-C-106 dome temperature } \\
\text { data for Flammable Gas Process } \\
\text { Test }\end{array}$ & $2.4,4.6$ & S980204-5 & EXCEL97 \\
\hline $\begin{array}{l}\text { Development of the 296-P-16 and } \\
\text { 296-C-0)6 ventilation systems } \\
\text { models }\end{array}$ & N/A & N980204-2 & Pro-Notes \\
\hline $\begin{array}{l}\text { Development of Tank 241-C-106 } \\
\text { and 241-AY-102 benchmark } \\
\text { models (work in progress) }\end{array}$ & N/A & N-980204-3 & Pro-Notes \\
\hline
\end{tabular}

${ }^{3}$ Registered trademark of John Marvin, Inc. 


\begin{tabular}{|c|c|c|c|c|c|}
\hline \multicolumn{6}{|c|}{ DISTRIBUTION SHEET } \\
\hline \multirow{2}{*}{$\begin{array}{l}\text { To } \\
\text { Distribution }\end{array}$} & \multirow{2}{*}{\multicolumn{3}{|c|}{$\begin{array}{l}\text { From } \\
\text { Process Analysis/8C } 453\end{array}$}} & \multicolumn{2}{|l|}{ Page 1 of 1} \\
\hline & & & & \multicolumn{2}{|l|}{ Date $7 / 10 / 98$} \\
\hline \multirow{2}{*}{\multicolumn{4}{|c|}{$\begin{array}{l}\text { Project Title/Work Order } \\
\text { W-320/D2MA1 }\end{array}$}} & \multicolumn{2}{|c|}{ EDT No. 625625} \\
\hline & & & & \multicolumn{2}{|l|}{ ECN No. } \\
\hline Name & MSIN & $\begin{array}{l}\text { Text } \\
\text { With All } \\
\text { Attach. }\end{array}$ & Text Only & $\begin{array}{l}\text { Attach./ } \\
\text { Appendix } \\
\text { Only }\end{array}$ & $\begin{array}{l}\text { EDT/ECN } \\
\text { Only }\end{array}$ \\
\hline
\end{tabular}

Lockheed Martin Hanford Corporation

K. J. Anderson

J. E. Andrews

S5-05

D.A. Bragg

G. N. Hanson

S5-04

S5-05

W. M. Harty

S5-07

S5-13

J. Lohrasbi

S5-05

W. J. Powell

S5-13

R. L. Powers

S5-13

$x$

$x$

$x$

$x$

$x$

$x$

$x$

$x$

John Marvin, Inc.

D. M. Ogden (5)

H5-49

H5-49

$x$

M. J. Thurgood

Numatec Hanford Corporation

J.W. Bailey

R. R. Bevins

S2-48

$\mathrm{S} 2-48$

$\mathrm{H} 6-35$

A.F. Choho

S2-48

J. W. Lentsch

H5-25

W. C. Miller

K. Sathyanarayana (5)

J.P. Sloughter

$\mathrm{HO}-34$

H5-49

Central Files (Original +2 )

A3-88

$x$

SGN Eurisys Services Corporation

J. R. Bellomy

$\mathrm{S} 2-48$

$\mathrm{S} 2-48$

$x$

S W. Shaw

S7-14

$\mathrm{S} 7-14$
$\mathrm{R} 1-43$

D. R. Bratzel

$x$
$x$
$x$

T. C. Geer

R1-43

$\mathrm{x}$
$\mathrm{x}$
$\mathrm{x}$
$\mathrm{x}$
$\mathrm{x}$
$\mathrm{x}$
$\mathrm{x}$
$\mathrm{x}$

